ISSN:2528-9527

E-ISSN : 2528-9535

YIl Year: 8

Cilt Volume: 8

Sayı Issue :14

\title{
Suriyeli Mülteci Kadınların Kuma Dramı: Kilis İli Örneği
}

DOI: $10.26466 /$ opus.406308

\section{İpek Agcadağ Celik ${ }^{*}$ - Feride Vural ${ }^{* *}$}

\author{
* Dr. Öğr. Üyesi, Kilis 7 Aralık Üniversitesi, Fen-Edebiyat Fakültesi, Kilis / Türkiye \\ E-Posta: ipekagcadag@kilis.edu.tr ORCID: 0000-0002-2409-668X \\ *Y. L. Öğrencisi., Sakarya Üniversitesi, Sosyal Bilimler Enstitüsü, Sakarya/ Türkiye \\ E-Posta: feridevrl.fv@gmail.com ORCID: 0000-0003-2441-9044
}

\section{Öz}

Suriye'de başlayan iç karışıklıların beraberinde getirdiği insanlık krizinin ardından, Suriye'den diğer ülkelere yoğun bir biçimde göç başlamış ve bu göçten etkilenen ülkelerin en başında ise, Suriyeli mültecilerin en fazla giriş yaptığı ülke olan Türkiye etkilenmiştir. Uygulanan açık kapı politikasıyla Suriye'den gelen insanların hepsine kucak açılmış ve bunun sonucunda üç buçuk milyonu aşan sayıda Suriyeli mülteci başta ülkemizin sınır şehirleri olmak üzere dört bir tarafina dağılmıştır. Bu dağılım, hem mülteciler hem de yerel halk için bir an önce kabul edilmesi gereken yeni gerçekleri, sorunları ve çözüm önerilerini de gündeme getirmiştir. Ülkemizde bu gerçeklerle en fazla yüzleşmesi gereken şehirlerden biri ise, şehirdeki Suriyeli mültecilerin yoğunluğu nedeniyle Kilis olmuştur. Hem yerel halk hem de Suriyeli mültecilerin bu sürece uyum sağlama ve birbirleriyle kaynaşma konusunda yoğun bir çaba gösterdikleri görülmektedir. Yerel halktan farklı ekonomik, sosyal ve kültürel yapılara sahip olan mültecilerin yaşam tarzları ve hayata bakış açıları farkllık göstermektedir. Bu farklılıklardan birini de evliliğe ve aile kurumuna bakış açıları oluşturmaktadır. Ülkemizde giderek azalan ve artık geçmişte olduğundan daha az yoğunlukta gündemimizi meşgul eden "çok eşlilik" ve "kumalık" konularmın, Suriye toplumunda hâlâ oldukça yaygin bir uygulama olduğunu ve Suriyeli mültecilerin ülkemizde de bu uygulamaya devam ettiklerini görmekteyiz. Suriyeli mültecilerin beraberlerinde getirdikleri bu kültürel geleneğin Kilis'te oldukça fazla göze çarptığını ve bazı kesimler tarafindan özendirici bir özelliğe sahip olduğunu görmekteyiz. Kilis'te yaşamlarını sürdüren ve kocaları çok eşli toplam 14 kadınla yapılan derinlemesine görüşmeler sonucunda ise, erkekler için özendirici bir uygulama olmakla birlikte, kadınlar için çok zor, acılı ve yıpratıcı bir durum olduğu görülmüştür.

Anahtar Kelimeler: Zorunlu göç, Suriyeli mülteciler, Kadın mülteciler, Çok eşli evlilik, Kumalık 


\title{
Second Wife Dram of Syrian Refugee Women: Kilis Sample
}

\begin{abstract}
Along with humanitarian crisis which has been raised by internal turmoil started in Syria the extensive immigration from Syria to other states began. Turkey, the country which hosted the largest number of Syrian refugees, is one of the states most affected by this immigration. As a result of the "open door" policy, Turkey accepted in border cities more than three and a half million Syrian refugees who further spread out on all four size of the country. This allocation has brought about new realities, problems and their possible solutions for the refugees and local people. One of the cities that faced the most with these realities in our country due to concentration of Syrian refugees is Kilis city. Both local people and Syrian refugees seem to be making an intensive effort to adapt to this process and to integrate with each other. The lifestyles and lifelong perspectives of refugees, who have different economic, social and cultural structures, are differ from local's ones. One of these differences is the angle of marriage and family institution. We can see that "polygamy" and "second wife" topics, which are gradually decreasing in our country and occupying our agenda less intensely than they were in the past, are still quite common practice in Syrian society and that Syrian refugees continue this in our country. This cultural tradition brought by the Syrian refugees is highly visible in Kilis and has an incentive characteristic by some segments. As a result of in-depth interviews with 14 women from Kilis whose husbands are multifaceted, this issue has been found to be a very difficult and painful for women, together with being an incentive practice for men.
\end{abstract}

Keywords: Forced migration, Syrian refugees, Women refugees, Polygamy, Second wife

OPUS (c) Uluslararası Toplum Araştırmaları Dergisi-International Journal of Society Researches ISSN:2528-9527 E-ISSN : 2528-9535

http://opusjournal.net 


\section{Giriş}

Suriye' de yaşanan insanlık krizinin üzerinden geçen yedi yıl ile birlikte, sadece Suriye'de değil, hem ülkemizde hem de başta bölge ülkeleri olmak üzere dünyanın pek çok ülkesinde pek çok değişim yaşanmıştır. Suriye' de çıkan iç çatışmalarda pek çok masum insan can vermiş, pek çoğu da yaralanmış, yakınlarını, evlerini, sahip oldukları maddi olanaklarını kaybetmiş ve ülkelerini terk etmek zorunda kalmışlardır. Hem kendilerinin hem de ailelerinin can güvenliğinden endişe eden milyonlarca insan ülkelerini terk ederek dünyanın dört bir tarafına dağılmışlardır. Özellikle Suriye'ye sınırı bulunan ülkeler görülmemiş bir mülteci akını ile karşı karşıya kalmışlardır. Suriye sınırına olan yakınlığından dolayı bu göç dalgasından en çok etkilenen ülkelerin başında ise Türkiye gelmiştir. Türkiye, uyguladığı "açık kapı" politikasıyla birlikte, ülkeye sığınmak isteyen tüm Suriye Arap Cumhuriyeti vatandaşlarına izin vermiş ve yardım eli uzatmıştır. Önce can güvenliği sağlanan bu insanlara sonrasında ihtiyaç duydukları her tür yardım için seferber olunmuştur. Bu süreçte Türkiye'de "geçici koruma statüsü" kapsamına alınan Suriyeli mülteciler, öncelikle sınıra yakın şehirlerimizde kurulan barınma merkezlerine yerleştirilmişlerdir. Ancak Suriye'deki çatışmaların devam etmesi ile birlikte ülkemize giriş yapan Suriyeli mültecilerin say1sı her geçen gün hızla artmıştır. Bu artışla birlikte ülkemiz barınma merkezleri, kalabalık Suriyeli mülteci kitlesinin hem barınma hem diğer ihtiyaçlarını karşılamak noktasında yetersiz kalmış ve mülteciler ülkemizin sınır şehirlerinin merkezlerine ve diğer şehirlere dağılmışlardır. Oldukça dinamik bir yapı gösteren bu dağılımın, çatışmaların başladığı tarihin üzerinden geçen yedi yıl ile birlikte hâlâ devam etmesi ise birçok sorunu da beraberinde getirmiştir. T.C. Başbakanlık Göç idaresi Genel Başkanlığ1 ülkemize giriş yapan, barınma merkezlerinde yaşayan ve bu merkezler dışında şehir merkezlerinde yaşayan Suriyeli mülteciler ile ilgili verileri paylaşmakta fakat kurumun paylaştığı verilerin oldukça sık yenilendiği göze çarpan önemli noktalardan biri olmaktadır. Bu durumun sebebi, hâlâ her geçen gün yeni mültecilerin ülkemize giriş yapmaları ve daha önce giriş yapan mültecilerin ise Türkiye içinde sürekli yer değiştirmeleri, böylece her şehrin ev sahipliği yaptığı mültecilerin sayısının neredeyse her gün değişim göstermesidir. Bu hareketlilikten nasibini en 
çok alan şehirler ise, ülkemizin sınır şehirleri olmaktadır. Bu şehirlerde bulunan sınır kapıları, barınma merkezleri ve şehir merkezleri bu göç sürecinde sürekli hareketliliğin yaşandığı noktalar haline gelmiştir. Yoğun bir Suriyeli mülteci nüfusunu bünyesinde barındıran bu şehirlerin yerel yönetimleri barınma, istihdam, sağlık, eğitim ve güvenlik gibi konuları içeren ekonomik, sosyal, kültürel ve psikolojik çok boyutlu bir sorun yumağını çözmekle uğraşmaktadırlar. Sadece yerel yönetimler değil, aynı zamanda sınır kentlerinde yaşayan yerli halk da Suriyeli mülteciler de bu yeni düzene uyum sağlamaya çalışmaktadırlar. Geçen yıllarla birlikte güvenlik, barınma, istihdam, sağlık ve eğitim gibi temel sorunların bir nebze de olsa aşılması ve hem yerli halkın hem de mültecilerin bu yeni düzene uyum sağlamaya başlamasıyla birlikte ise yavaş yavaş sosyo-kültürel farklılıklar su yüzüne çıkmaya ve fark edilmeye başlanmıştır. Castles ve Miller (2008)'ın da belirttiği gibi, "göç eden insanların gelenekleriyle, dinleriyle, alışkanlıklarıyla farklı olan toplumlardan geldiklerini, farklı dilleri konuştuklarını ve kültürel pratiklerinin farklı olduğunu; gittikleri ülkelerde kültürel olarak dillerinin ve kültürlerinin bazı unsurlarını en az birkaç kuşak boyunca koruduklarını göstermektedir". Ülkemizde özellikle sınır kentlerde mülteci yoğunluğundan dolayı daha kolay göze çarpan ve kentlerin gündem konularından biri haline gelen farklılıklardan biri ise, Suriyeli mültecilerin aile yapılaridır.

Geleneksel ve ataerkil bir yapı sergileyen Suriye toplumunda, kadınerkek ilişkileri, kadın ve erkeğin toplumdaki ve aile içindeki yeri incelendiğinde, toplumsal düzen ve yapının kadınların aleyhine işleyen bir şekilde düzenlendiğini görmekteyiz. Bu mekanizmanın en bariz şekilde; evlilik kararı, evlilik töreni, aile yaşamı, çocuk sahibi olma ve çocuk sayısı kararı, evlilik hayatında alınması gereken önemli kararlar, çocukların hayatı ve geleceği için alınan kararlar, boşanma kararı gibi sayabileceğimiz pek çok konuda kendini gösterdiğini ve kadının bu konularda nerdeyse hiç söz hakkının olmadığını söyleyebiliriz. Bu duruma verilebilecek en güzel örnek ise şüphesiz Suriye Arap Cumhuriyeti'nde dinin referans alınarak erkeklere dört eşle evlenme hakkının yasal olarak tanınmasıdır. Kadınların Suriye toplumunda yukarıda saydığımız konular (evlilik kararı vb.) ve eşlerinin kendilerinden başka kadınlarla da evlenebil- 
mesinin getirdiği sıkıntılar ve acılar insan olarak bizi üzmesinin yanı sıra konunun bizi son zamanlarda daha fazla ilgilendiren ve etkileyen tarafi ise, Suriye'den Türkiye'ye yapılan zorunlu göçlerle birlikte, Suriyeli kadınlarla artık aynı yaşam alanlarını paylaşmamızdır. Bu paylaşımla birlikte, onların yaşamlarına ve acılarına çok daha yakından şahit olmaktayız. Ülkelerinde meydana gelen olumsuz şartlardan etkilenmiş, yakınlarını kaybetmiş, evlerini kaybetmiş ve yaşamlarını arkalarında bırakarak yeni bir ülkeye ve hayata adım atan Suriyeli mülteci kadınların, yeni hayatlarında da peşlerini bırakmayan ve yüzlerini güldürmeyen konunun maalesef çok eşlilik ve "kuma"lık olduğunu görmekteyiz. Kendi ülkelerinde, erkekler birden fazla kadınla yaptıkları evliliklerin yarattığı sıkıntıları, eşlerin her birine ayrı evler ya da yaşam alanları temin ederek kendilerince çözüm bulmaktadırlar. Ancak savaş ortamından ülkemize sığınma süreciyle birlikte, yaşadıkları maddi ve manevi zorluklar neticesinde erkeklerin büyük bir kısmının ülkemizde eşlerine ayrı yaşam alanı açma fırsatı olmadığı için hep birlikte yaşamak zorunda kaldıklarını gözlemlemekteyiz. Bu gözlem ise bizleri, bu kadınların hem ülkelerinde hem de ülkemizde sürdürdükleri evlilik ve aile yaşamlarına ilişkin hikâyelerini öğrenmeye itmiştir. Bu merakla birlikte, hem Suriye'den yapılan göç konusunda ülkemizin önemli noktalarından biri haline gelmiş hem de yüzölçümü ve nüfusu göz önüne alındığında bünyesinde en yoğun Suriyeli mülteci kitlesini barındıran ve dolayısıyla şehrin günlük yaşamı içerisinde oldukça fazla Suriyeli mülteciyle bir araya gelinen ve bizzat bu şehirde yaşanıldığı için gözlem yapma, bilgi ve tecrübe edinme şansı daha yüksek olan Kilis şehrinde araştırma yapılmıştır. Bu araştırmada, çok eşlilik ve kumalığın oldukça hassas, mahrem ve derin bir yapısının olması nedeniyle, nitel bir araştırma yönteminin bir veri toplama tekniği olan derinlemesine görüşme tercih edilmiştir. Ülkemizde yaşayan Suriyeli mültecilerin; kadınlara, evliliğe, aile yaşamına ve özelikle çok eşliliğe bakış açılarının ve tecrübelerinin incelendiği bu araştırma, Türkiye' de yapılan ilk çalışma olma özelliğini taşımaktadır. Bu araştırma sonrasında, Kilis'te yaşayan 14 Suriyeli mülteci kadının yaşam hikâyelerine, çok eşlilik konusundaki deneyimlerine ve bakış açılarına ulaşılmıştır. Böylece bu çalışma, Suriye'den Türkiye'ye yapılan göç, göç sonrası Kilis şehri ve Suriyeli mülteciler ile Suriyeli mülteci kadınların çok eşlilik deneyimleri konularına odaklanmaktadır. 


\section{Türkiye'ye Sığınan Suriyeli Mülteciler}

Suriye Arap Cumhuriyeti'nde meydana gelen olaylar sonucu ülkeden kaçan 252 kişilik ilk grup, 29 Nisan 2011 tarihinde Hatay'ın Yayladağ1 İlçesi Güveççi Köyü bölgesinden giriş yapmıştır. Suriye' deki şiddet olaylarının artmasına paralel olarak hem bu bölgeden hem de Hatay'ın Alttnözü ve Reyhanlı başta olmak üzere diğer bölgelerinden de girişler devam etmiştir. Bu girişler içinde bulunduğumuz 2018 yılında da devam etmekte ve makalenin yazıldığı tarih itibariyle 3.540.648 gibi bir rakama ulaşmıştır. Suriye vatandaşlarının kitlesel olarak ve yoğun biçimde sınır noktalarına gelmeleri üzerine kendilerine "geçici koruma" statüsü verilerek çadır kent, konteyner kent ve diğer konaklama biçimlerinde barındırılmak suretiyle koruma altına alınmışlardır. Geçici koruma statüsünün sonucu olarak, açık kapı politikası uygulanmakta ve rızası dışında kimsenin geri gönderilmemesi ilkesi benimsenmekte, güvenlikleri tam olarak sağlanmakta ve insani yardımlar yapılmaktadır (TBMM, 2014, s. 2).

Birleşmiş Milletler Mülteciler Yüksek Komiserliği (BMMYK) 'nin verilerine göre, Türkiye, Lübnan, Irak, Ürdün ve misır gibi bölge ülkelerde mülteci olarak kayda alınan Suriyeli mültecilerin sayısı beş milyonu aşmış; savaşın başlamasından bu yana üç milyonu aşan Suriyeliye kapılarını açan Türkiye ise bölgede en fazla sığınmacı bulunan ülke konumuna gelmiştir.

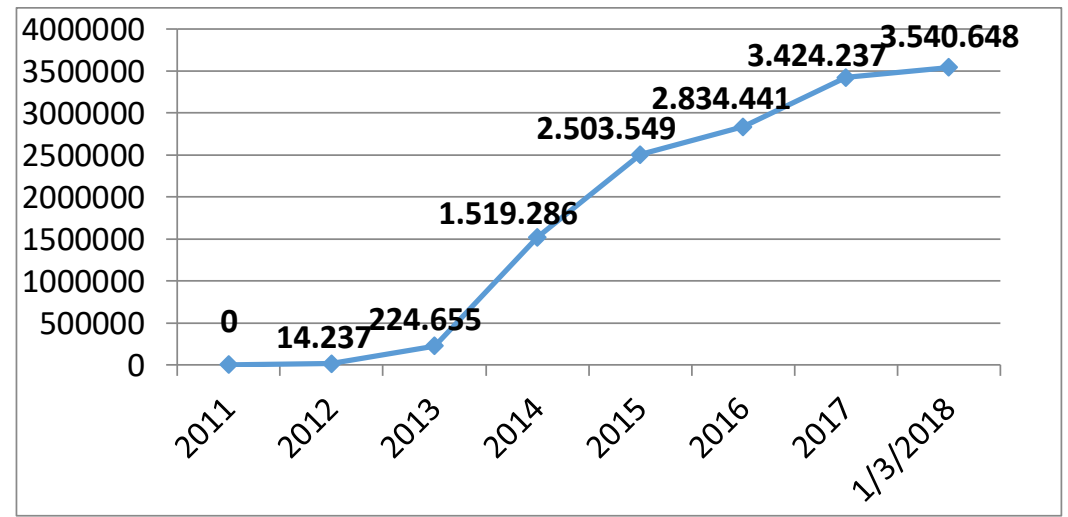

Grafik 1. Yıllara Göre Geçici Koruma Kapsamındaki Suriyeliler 
Türkiye'ye gelen Suriyeliler ilk aşamada sadece sınır illerinde ve kamplarda ikamet etmişlerdir. İç savaşın uzaması ile kamp sayısı yetersiz kalmaya başlamış, kamplardan bağımsız olarak bir kısım Suriyeli kamplar yerine, sınır illerinde veya ilçelerinde akrabalarının yanında ya da kiraladıkları evlerde ikamet etmeyi tercih etmeye başlamışlardır (Güçtürk, 2014).

Tablo 1. Geçici Koruma Kapsamındaki Suriyelilerin Geçici Barınma Merkezlerine Göre Dağılımı

\begin{tabular}{lc}
\hline Geçici Barınma Merkezleri & Toplam \\
\hline Şanlıurfa & 81.064 \\
\hline Gaziantep & 24.048 \\
\hline Kilis & 25.293 \\
\hline Kahramanmaraş & 17.225 \\
\hline Mardin & 2.761 \\
\hline Hatay & 17.485 \\
\hline Adana & 26.946 \\
\hline Adıyaman & 9.062 \\
\hline Osmaniye & 14.863 \\
\hline Malatya & 9.450 \\
\hline Toplam & $\mathbf{2 2 8 . 1 9 7}$ \\
\hline Geçici Barınma Merkezleri Dişında Kalan Suriyeli Sayısı & $\mathbf{3 . 3 1 2 . 4 5 1}$ \\
\hline Ülkemizde Bulunan Toplam Suriyeli Sayısı & $\mathbf{3 . 5 4 0 . 6 4 8}$ \\
\hline
\end{tabular}

Türkiye iyi donanımlı kampları kısa sürede hizmete koyarak mülteci akınına yönelik ilk müdahaleyi yapmış ancak kamplar kısa vadeli bir probleme çözüm niteliğinde kurulmuştur. Suriye'deki savaşın uzaması, Nisan 2011'deki ilk mülteci akınından sonra Türkiye'ye giren Suriyelilerin sayısının hızla artmasına sebep olmuştur. Bunların yaklaşık yüzde doksanı kamp alanlarının dışında; çoğunlukla ülkemizin Güneydoğu bölgesindeki kentlerde, Ankara ve İstanbul gibi diğer kentlerde yaşamlarını sürdürmektedirler (Orsam, 2015: 9).

Türkiye'ye göç eden 3 milyon 540 bin 648 Suriyelinin yaklaşı 1,5 milyonu sınır kentleri; Kilis, Hatay, Şanlıurfa, Gaziantep ve Mardin'i tercih etmiştir. Sınır kentlerinden Kilis; Suriyeli mültecilerin sayısının (130.375), yerli halkın sayısına (136.319) en yakın olan şehirdir. Rakam- 
lardan da anlaşılacağ üzere, Kilis, neredeyse her iki kişiden birinin Suriyeli mülteci olduğu bir şehir haline gelmiştir.

Tablo 2. Nüfusuna Oranla Türkiye'de En Çok Suriyeli Sı̆̆ınmacı Barındıran İlk 10 İl

\begin{tabular}{lllll}
$\begin{array}{l}\text { İ } \\
\text { Sırası }\end{array}$ & İller & $\begin{array}{l}\text { Suriyeli } \\
\text { Sayısı }\end{array}$ & $\begin{array}{l}\text { Şehir } \\
\text { Nüfusu }\end{array}$ & $\begin{array}{l}\text { İl Nüfusu İle Karşılaştırma } \\
\text { Yüzdesi }\end{array}$ \\
\hline $\mathbf{1}$ & Kilis & 130.375 & 136.319 & $95,64 \%$ \\
\hline $\mathbf{2}$ & Hatay & 451.058 & 1.575 .226 & $28,63 \%$ \\
\hline $\mathbf{3}$ & Şanlıurfa & 477.209 & 1.985 .75 & $24,03 \%$ \\
\hline $\mathbf{4}$ & Gaziantep & 370.646 & 2.005 .515 & $18,48 \%$ \\
\hline $\mathbf{5}$ & Mersin & 203.229 & 1.793 .931 & $11,33 \%$ \\
\hline $\mathbf{6}$ & Mardin & 91.526 & 809.719 & $11,30 \%$ \\
\hline $\mathbf{7}$ & Osmaniye & 53.202 & 527.724 & $10,08 \%$ \\
\hline $\mathbf{8}$ & Kahramanmaraş & 100.042 & 1.127 .620 & $8,87 \%$ \\
\hline $\mathbf{9}$ & Adana & 188.712 & 2.216 .475 & $8,51 \%$ \\
\hline $\mathbf{1 0}$ & Kayseri & 71.890 & 1.376 .722 & $5,22 \%$
\end{tabular}

Kilis nüfusunun (136.319) yaklaşık \%95.64'lük oranına tekabül eden 130.375 Suriyeli mülteciye ev sahipliği yapmakta ve bu oran Kilis'i, Türkiye'nin kendi nüfusuna oranla en yüksek oranda Suriyeli mülteciyi barındıran şehri haline getirmektedir. Kilis'ten sonra sırasıyla, Hatay şehir nüfusunun \%28,63'üne, Şanlıurfa \%24,03'üne, Gaziantep $\% 18,48^{\prime}$ ine, Mersin \%11,33'üne, Mardin \%11,30'una, Osmaniye $\% 10,08$ 'ine, Kahramanmaraş \%8,87'sine, Adana \%8,51'ine ve Kayseri $\% 5,22$ 'sine karşılık gelen rakamlarda Suriyeli mültecilere ev sahipliği yaparak, ülkemizde nüfusuna göre en yüksek oranda Suriyeli mülteci barındıran ilk on şehir unvanına sahip olmaktadırlar. Suriyeli mülteciler Türkiye' nin tüm illerine dağılmakla birlikte, en fazla, Tablo 2'de görüldüğü üzere, ülkemizin sınır kentlerinde yoğunlaşmaktadırlar. Suriyeli mültecilerin sınır kentlerini tercih etmelerinde ise, Suriye'den Türkiye'ye geldiklerinde bu sınır kentlerde kurulan geçici barınma merkezlerine (çadır kent ve konteyner kentler) yerleşmeleri, zaman ilerledikçe kent merkezlerinde yaşamaya başlayarak buralarda iş bulup çalışmaları, çocuklarının bu kentlerde okula başlaması, akrabalarının ve yakınlarının buralarda bulunmasının yanı sıra ülkelerinde yaşanan savaşın son bulması ve huzurun sağlanmasının ardından ülkelerine geri dönmelerinin bu kentlerden daha kolay ve hızlı olacağını düşünmelerinin etkisi bu- 
lunmaktadır. Sınır kapısından (Öncüpınar) geçen Suriyeli mültecilerin büyük bir kısmının Türkiye' de ilk ayak bastıkları şehir olan Kilis ise, Suriyeli mültecilerin bir bölümünün geçici barınma merkezlerine yerleşmelerinin yanı sıra büyük bir bölümünün şehir merkezine akın edip yerleştikleri, kalan bölümünün de bu şehirden Türkiye'nin diğer illerine geçtikleri önemli sınır kentlerinden olup bu özellikleri nedeniyle araştırma kapsaminda incelenmektedir.

\section{Suriye'den Türkiye'ye Yapılan Zorunlu Göçün Kilis İlindeki Yansıma- ları}

Suriye sınırına 10 kilometre mesafede bulunan ve Suriye de savaşın başladığ 2011 yılından bu yana binlerce mülteciye ev sahipliği yapan Kilis, 136.319 kişiden oluşan yerli nüfusun yanı sıra, 130.375 Suriyeli mülteciye de ev sahipliği yapmaktadır. Bu rakamlarla birlikte, bu küçük sınır kenti, nüfusuna oranla Türkiye'de en yoğun Suriyeli mülteciyi barından kenti haline gelmiştir.

Göçler coğrafi mobilite şeklinde olduklarından; göç edenler yaşam biçimlerinin, alışkanlıklarının, inançlarının yanı sıra sorunlarını da gittikleri ülkeye taşımaktadırlar. Bundan dolayı göçler, hem göçmenlerin hem de göç edilen toplumların yaşamlarında hem zenginliklere hem de sorunlara neden olmaktadır. Böylece göçlerin ekonomik, sosyal ve kültürel bakımdan çok boyutlu bir olgu olduğu görülmektedir (Elma ve Şahin, 2015: 430-431). İmkânları sınırlı olan bu kente, kendi nüfusundan fazla Suriyeli mültecinin gelmesi, Kilis'in günlük hayatında ekonomik, sosyal ve kültürel değişimleri beraberinde getirmiştir.

\section{Kilis'te Yaşayan Suriyeli Mülteciler ve Barınma}

Suriyeli mültecilerin Kilis'e geldiklerinde barınmak amacıyla tercih ettikleri ilk noktalar, geçici barınma merkezlerin (konteyner kentler) olmuştur. Kilis'te biri Suriye sınırına on kilometre mesafede Öncüpınar Barınma Merkezi, diğeri ise Kilis'in Elbeyli İlçesi'nde Elbeyli Barınma Merkezi olmak üzere iki adet geçici barınma merkezi kurulmuştur. Suriye'de yaşanan sorunların ardından Suriye' den Kilis sınırına yoğun bir mülteci akını olmasıyla birlikte, hızlı bir şekilde Kilis'te barınma merkezleri inşa 
edilmiş ve mültecilerin bu merkezlere yerleşmeleri sağlanmıştır. Son verilere (01.03.2018 itibariyle) göre, 25.293 kişinin kaldığı bu merkezlerde, Suriyeli mülteciler, her birinde şofben, ocak, ısıtıcı ve buzdolabı yer aldığı tek katlı ve çift katlı konteynerlerde yaşamaktadırlar. Geçici barınma merkezlerinde Suriyeli mültecilerin günlük ihtiyaçlarını karşılamak adına okullar (kreş, anaokulu, ilkokul, ortaokul, lise, TÖMER), sağlık birimleri (hastane, 112 acil servis, diş poliklinikleri, sağlı ocağı, eczane), spor alanları, sosyal imkânlar, çocuk park alanları, ibadethane ve psiko-sosyal destek ve merkezi bulunmaktadır.

Kilis'te geçici barınma merkezlerinin yanı sıra şehir merkezlerinde yaşayan Suriyeli mülteciler de bulunmaktadır. Şehir nüfusuna oranla sayıları oldukça fazla olan (105.082 kişi) Suriyeli mülteciler, şehrin dört bir yanına dağılmıştır. Şehrin her tarafına yayılmakla birlikte, şehrin merkezi noktalarını daha fazla tercih ettikleri görülmektedir. Kendilerinden daha önce göç eden Suriyeli hemşerilerinin bulundukları mahalleler ve evler bu tercihte oldukça etkili olmaktadır. Ayrıca Suriyeli mültecilerin şehir merkezinde yoğun bir biçimde yaşamalarıyla birlikte ev kiralarında büyük bir artış yaşanmıştır. Şehrin diğer mahallelerine kıyasla bu mahallerdeki kiraların görece daha düşük olması, işyerlerine daha yakın olması, evlerine yakın okulların bulunması ve Suriyeli komşularının yanı sıra Suriyeli esnafların dükkânlarının da bu mahallerde de daha yoğun bir biçimde bulunması gibi nedenlerle Suriyeli mülteciler, bu mahalleri daha fazla talep etmişlerdir.

Suriyeli mültecilerin bu şehirde müstakil evleri, gecekonduları ve apartman dairelerinde yaşamlarını sürdürmektedirler. Bu konut biçimlerinin içinde Suriyeli mültecilerin ilk tercihleri, eski Kilis evleri denilen müstakil yapılardan yana olmuştur. Eski Kilis evleri, bahçeli, bahçesi duvarlarla çevrildiği için içeriyi göstermeyen, tuvalet, mutfak ve banyonun bahçede olduğu, iki veya üç odalı, odalarda 1sınma aracı olarak sobaların kullanıldığı evlerdir. Çok eşli evlilik yapan Suriyeli mülteci erkekler, özellikle eşlerinin aynı evde kalması gerektiği durumlarda bu evlere oldukça fazla rağbet göstermektedirler. Bu evlerde, Suriyeli eşlerin her birine bir oda düşmekte böylece erkek haftanın belirli gecelerini bir odada, diğer gecelerini diğer oda/odalarda geçirebilmektedir. Evin bahçesinin duvarlarla çevrili olması sayesinde, evin içi ve bahçesi diğer 
insanlar tarafından görülmemekte, böylece evin erkeği ev mahremiyetini sağlamış olmanın rahatlı̆̆ını yaşamaktadır. Ayrıca evin bahçesi, kadınların tümünün çocukları için ortak yaşam ve oyun alanı haline gelmektedir. Evin bahçesi, aynı zamanda, kadınların birlikte kullanabileceği mutfak, tuvalet ve banyo gibi ortak kullanım alanlarına sahiptir.

Suriyeli mültecilerin Kilis'te apartman dairelerinde de yaşadıkları gözlemlenmekle birlikte, özellikle erkeğin birden fazla eşinin olması, erkeğin her biri için ayrı daire tutacak maddi gücünün olmaması, çok sayıda çocuğun aynı evde yaşamasından dolayı oluşan gürültü nedeniyle komşularla sıkıntı yaşanması ve apartman dairelerinin kiralarının müstakil evlerden fazla olması gibi nedenlerle daha az tercih edilmektedir. Apartman daireleri genellikle maddi durumları görece daha iyi olan Suriyeli çekirdek aileler tarafından tercih edilmektedir. Eski Kilis evleri, müstakil evler ve apartman daireleri dışında, dükkânlarda ve barakalarda yaşayan daha az sayıda Suriyelilere rastlanmaktadır.

\section{Kilis'te Yaşayan Suriyeli Mülteciler ve İstihdam}

Suriye Arap Cumhuriyeti vatandaşlarının, Suriye'de yaşanan krizin patlak vermesiyle birlikte ülkede yaşanan savaş ortamından kaçmalarının ardından geçen yaklaşık yedi yıl ile birlikte ülkemiz, sadece büyük bir mülteci akını ile karşı karşıya kalmamış; aynı zamanda mültecilerin kalış sürelerinin her geçen gün uzamasıyla birlikte sosyo-ekonomik sorunlarla da yüzleşmek zorunda kalmıştır. Bu nedenle hem mülteciler hem de özellikle ülkemiz sınır kentlerinin yerli halkı günlük yaşamlarında göç ile birlikte ortaya çıkan yeni gelişmelere ayak uydurmak durumunda kalmışlardır. Yaşar (2014)'ın da belirtiği gibi;

"Yeni şartlara uyum süreci aynı zamanda yabancılaşma süreci olduğundan bu durum sadece göçmenler açısından değil onların muhatabı yerli insanlar açısından da sorundur. Ulus aşırn göçlerde statü ve roller, kalıplanmış ilişkiler, sosyal bağ ve alışkanlıklar değiştiğinden insanların kimlikleri, hatta kişilikleri bile sarsıllır. Yeni şartlar alışıldık yöntemlerle başa çıkılacak cinsten olmadığından, farklı yer, kültür, yeni zorluklar, farklı dil, kural ve değerler sı̆̆ımmacıları sudan çıkmış 
balı̆̆a çevirmektedir. Her şeye yeni baştan başlamak gerektiğinden karşılaşılan hemen her şey meydan okuyucudur."

Şehir merkezlerinde yaşayan Suriyeli mültecilerin barınma problemini bir şekilde çözüp aileleri ile birlikte kendilerine kalacak bir yer bulduklarında halletmeleri gereken bir sonraki mesele, yaşamlarını devam ettirebilmek için gerekli maddi imkânlara sahip olabilmektir. Suriyeli mülteciler, yeni geldikleri ve dillerini bilmedikleri Türkiye'nin kentlerinde, yaşamlarını sürdürebilmek için iş bulmak ve gelir sağlamak zorunda kalmaktadır. Üstün (2016)'ün de belirttiği gibi, Suriye'deki iç çatışmanın gittikçe uzamasıyla birlikte, Türkiye'ye göç eden Suriyeli mültecilerin ellerindeki nakit birikimlerini tüketerek ailelerinin ihtiyaçlarını karşılayamayacak duruma gelmelerinden dolayı umutsuzluğa kapılmaları ve derneklerden ve devletten aldıkları yardımların yetersiz kalması nedeniyle bir an önce çalışmak zorunda kalmalarının vasıfsız iş gücü piyasasında rekabeti artırdığı görülmektedir.

Türkiye genelinde olduğu gibi Kilis'te yaşayan Suriyeli mültecilerin de yararlandığı en önemli ekonomik yardım olarak karşımıza öncelikle Yabancılara Yönelik Sosyal Uyum Yardım Programı (SUY) kapsamında Türkiye'de yaşayan ihtiyaç sahibi mültecilere ulaşmayı planlayan, çok amaçlı nakit yardımı çıkmaktadır. Avrupa Komisyonu'nun finanse ettiği, Türk Kızılay'ı, Aile ve Sosyal Politikalar Bakanlığı ve Birleşmiş Milletler Dünya Gıda Programı (WFP) işbirliği ile ülkemizdeki Suriyeli mültecilere her ay belirli miktarda para yardımı yapılmaktadır. Suriyeli mülteci ailelere, ailede bulunan kişi başına ayda 120 TL para yardımı yapılmaktadır. Türk Kızılay'ı tarafından dağıtımı yapılan ve "Kızılay Kart" adı verilen banka kartları aracılığı ile ihtiyaç sahipleri gıda, yakıt, kira veya ilaç gibi ihtiyaçlarını satın almakta ve faturalarını ödemektedirler. Ayrıca Sosyal Yardımlaşma Dayanışma Vakfı (SYDV), Suriyeli ailelere kışlık kömür yardımı yapmaktadır. Bu yardımların yanı sıra ihtiyaç sahibi Suriyeli mültecilere sosyal hizmet merkezi (SHM) tarafından "SED" adı verilen "sosyo-ekonomik destek" hizmeti de sağlanmaktadır.

Kilis'te yaşayan Suriyeli mülteciler, yukarıda bahsedilen yardımlardan yararlanmakla birlikte, aynı zamanda işgücü piyasasında da yer almaktadırlar. Şehir merkezinde Suriyeli kadınların ve kız çocukların, 
işgücü piyasasında erkeklere oranla daha az yer aldıkları gözlemlenmektedir. Bu durumun temel sebepleri arasında ailevi değerler, dini değerler, dil problemi, ev işleri ve çocuk bakım yükümlülügü gösterilebilmektedir. İşgücü piyasasında yer alabilen Suriyeli kadınların ve kız çocuklarının ise, kuaförlüğün ve terziliğin yanı sıra Arapça bilmelerinden dolayı Suriyeli kadın müşterilere hizmet vermeleri için genellikle kozmetik dükkânları, tekstil mağazaları ve marketlerde satış danışmanı olarak işe alındıkları gözlemlenmektedir. Ayrıca Suriyeli kadınlar; okul, hastane, belediye gibi kamu kurumlarının yanı sıra özel sektörde de "tercüman" olarak çalışmaktadırlar.

Suriyeli erkek mültecilerin, Kilis işgücü piyasasında yaptıkları faaliyetler incelendiğinde, ilk olarak küçük esnaf olarak adlandırılan "bağımsız çalışan grup" göze çarpmaktadır. Ülkelerinden küçük de olsa bir birikim ile Kilis'e gelen Suriyeli mülteciler, Kilis'te çeşitli kollarda (berber, bakkal, tuhafiye, kozmetik, lokanta, terzi, ayakkabı, kuruyemiş, mobilya, manav vb.) dükkânlar açmakta ve kazanç elde etmektedirler. Ekonomik bir birikime sahip olmayan Suriyeli erkek mültecilerin ise yerli halka veya diğer Suriyeli mültecilere ait yukarıda adı geçen dükkânlarda çalıştıkları görülmektedir. Suriyeli erkeklerin Kilis'te yaygın olarak yer aldıkları bir diğer sektör ise inşaat sektörüdür. Çok sayıda Suriyeli erkek çocuk ve yetişkin, inşaat işçisi olarak çalışmaktadır. Kilis'te çalışan Suriyeli erkek çocukların sayısı oldukça fazla olup bu çocuklar inşaat işçiliğinin yanı sıra, babalarına ya da başkalarına ait dükkânlarda garson, kasap çırağı, bakkal çırağı, berber çırağı, terzi ve baklavacı çırağı olarak çalışmakta ve ailelerine ekonomik katkı sağlamaktadırlar. Suriyeli çocuk işçilerin yanı sıra yıllar içinde azalmakla birlikte, çocuk dilencilere ve çöp toplayıcılarına da kentin sokaklarında rastlamak mümkündür. Ayrıca şehir merkezinde az sayıda da olsa, eğitim düzeyi yüksek Suriyeli mülteci erkeğin; doktor ve sağlık görevlisi olarak (sadece Bab-1 Şifa Göçmen Sağlığ1 Merkezi'nde), öğretmen olarak, kamu ve özel sektörde tercüman olarak istihdam edildikleri ve sivil toplum kuruluşlarında çeşitli pozisyonlarda çalıştıkları görülmektedir. 


\section{Kilis'te Yaşayan Suriyeli Mülteciler ve Sağlık}

Suriye' de yaşanan savaş ortamından gelen insanlar içinde fiziksel, zihinsel ve ruhsal rahatsızlıkları bulunanlar, 65 yaş üstü yaşlı bireyler, göç sürecinde yeni doğmuş bebekler, ülkemize geldikten sonra doğan bebekler ve genellikle erken yaşta evlendirilip çok sayıda çocuk doğurduğu için çeşitli hastalıkları bulunan kadınlar birlikte düşünüldüğünde, ülkemizde sağlık hizmetlerine ihtiyaç duyan çok sayıda mültecinin bulunduğu gerçeğini karşımıza çıkarmaktadır.

Sağlık Bakanlığı, 18 Ocak 2013 tarihinde, kayıtlı olsun veya olmasın ülkemizde bulunan bütün Suriyeli mültecilerin sağlık hizmetlerinden ücretsiz olarak yararlanabilmesi için bir genelge yayınlamıştır. Bu genelge ile Suriyeli mülteciler, Türk vatandaşlarına uygulanan kriterlerde sağlık hizmeti görme imkânına kavuşmuşlardır (Erdoğan, 2011, s. 19). $\mathrm{Bu}$ genelge doğrultusunda, Kilis'te bulunan kamuya ait hastane ve sağllk merkezlerinde, Suriyeli mültecilere ücretsiz olarak sağlık hizmeti sunulmuştur. Kilis ilinde Suriyeli mültecilere yönelik sağlık hizmetleri, geçici barınma merkezleri ve şehir merkezi olarak ikiye ayrılmaktadır. Geçici barınma merkezlerinin her birinde hastane, acil servis, diş poliklinikleri ve eczane bulunmakta olup Suriyeli mültecilere sağlık hizmeti verilmektedir. Ayrıca ihtiyaç halinde Kilis devlet hastanesine sevkler de gerçekleştirilmektedir. Şehir merkezinde ise, Kilis Devlet Hastanesi, Suriyeli mültecilerin sağlık hizmetlerinden faydalanmak için en yoğun başvurdukları sağlık kuruluşudur. Suriyeli mültecilerin ücretsiz olarak tedavi olabilmesi nedeniyle, Kilis Devlet Hastanesi' nde yerel halktan çok daha fazla sayıda Suriyeli mülteciye rastlanmakta (özellikle kadın hastalikları ve doğum polikliniklerinde) ve bu durum hastanede sürekli olarak kalabalık bir görüntü oluşturmaktadır. Kilis'te bulunan diğer sağlık kuruluşu Özel Aktürk Hastanesi'dir. Bu hastanede sağlık hizmetlerinin ücretli olması, bu sağlık merkezinin Suriyeli mülteciler tarafından daha az tercih edilmesini ve Kilis Devlet Hastanesi'ndeki Suriyeli mültecilerin yoğunluğundan huzursuz olan yerel halkın, bu hastaneye mültecilerden daha fazla talep edilmesini beraberinde getirmektedir. Kilis'te bulunan bir diğer sağlık kuruluşu ise, Avrupa Birliği'nin de katkılarıyla Sağlık Bakanlığı tarafından kurulan Bab-1 Şifa Göçmen Sağlı̆̆ı Merkezi'dir. Bu 
merkezde Suriye asıllı doktorlar ve sağlık görevleri istihdam edilerek, dil ve kültür farklılığı nedeniyle sağlık hizmetlerinden faydalanmakta güçlük çeken Suriyeli mültecilerin, sağlık hizmetlerine daha kolay ulaşabilmelerini sağlanmaktadır.

\section{Kilis'te Yaşayan Suriyeli Mülteciler ve Eğitim}

Türkiye' deki Suriyeli mültecilerin yaklaşık yarısını (1.618.877 kişi), eğitim çağındaki 0-18 yaş grubu oluşturmaktadır. Bu da iki milyona yakın Suriyeli öğrencinin eğitime devam etmesi gerçeğini ortaya çıkarmaktadır. Bu rakama 18 yaş üstü üniversite eğitimi yarıda kalanlar ile üniversite çağına gelenleri de eklediğimizde sorunun ciddiyeti daha açık görülmektedir. Türkiye'de Milli Eğitim Bakanlığı ve Yükseköğretim Kurulu (YÖK) genelgelerle Suriyeli öğrencilerin ilkokul, ortaokul, lise ve üniversitelere intibakının sağlanması yönünde çalışmalarını sürdürmektedir. $\mathrm{Bu}$ alanda öncelikli sorunlar, ciddi bir öğrenci sayısının varlığı, anadilde eğitim ve dil sorunudur. Büyük bir çoğunluk Türkçe bilmemektedir. Ayrıca Türkiye'deki eğitim kurumlarının bu yükü ne ölçüde kaldırabileceği hususu da ayrı bir tartışma konusudur (Elma ve Şahin, 2015, s. 436). Bu sorunların yanı sıra, erken yaşta yapılan evlilikler ve çocuk işçiliği de, çocukların eğitimlerinin yarıda kalmasındaki ciddi risk unsurlarıdır (Regional Progres Report, 2015, s. 20-21). Suriyeli mülteciler ve eğitim konusunu Kilis özelinde incelediğimizde, yukarıda bahsedilen sorunların, şehir merkezine oranla geçici barınma merkezlerinde daha az hissedildiği gözlemlenmektedir. Geçici barınma merkezlerinde kreş, okul öncesi eğitim, ilkokul, ortaokul düzeyindeki eğitime çok büyük oranda sağlandığı, lise düzeyi eğitime ise öğrencilerin yaklaşık yarısının katılım sağladığı görülmektedir. Bu okullarda hem Suriye asıllı hem de Türk öğretmenlerin çalışması ve kamplarda çocuk işçiliğinin olmaması çocukların eğitime katılım oranlarını yükseltmektedir. Geçici barınma merkezlerinde yaşayan gençlerin, Kilis 7 Aralık Üniversitesi'ne ve yakın illerdeki diğer üniversitelere devam ettikleri görülmektedir. Ayrıca lise mezunu yetişkinler için TÖMER (Türkçe Öğrenme Merkezi) tarafından verilen Türkçe kursunu başarıyla tamamlanması halinde, bireyler Türkiye'deki üniversitelerde eğitim-öğretim hakkına sahip olabilmektedirler. Bunların yanı sıra kurulan yetişkin eğitim merkezlerinde mesleği olmayan yetiş- 
kinlere yeterli beceriler kazandırılarak meslek sahibi olmalarına yardımcı olunmaktadır. Ayrıca çeşitli projelerle Suriyeli kadınların, mesleki ve kişisel gelişim atölyelerinde yaptıkları el işi ürünlerin (minder, yastık, peçete, takı ve cam aksesuar ürünleri vb.) mağazalara satılarak elde edilen gelirin üretici kadınlara dağıtımı da söz konusudur.

Kilis genelinde yalnızca Suriyeli çocukların eğitim gördüğü toplam yirmi adet Geçici Eğitim Merkezi bulunmakta, bu merkezlerin yedisi geçici barınma merkezlerinde olup diğerleri şehir merkezinde bulunmaktadır. Geçici eğitim merkezleri dışında Kilis'te yüz seksen adet Türk Okulu bulunmakta ve bu okullarda yerli öğrencilerin yanı sıra Suriyeli öğrenciler de eğitim-öğretim görmektedir. Bu okullarda öğretim dili Türkçe olup, hem Türk hem Suriyeli öğrencilere aynı Türkçe eğitim müfredatına göre hazırlanan dersler verilmektedir. Bu durum, bazı sorunları da beraberinde getirmektedir. Bu okullarda Türk öğretmenler çalışmakta ve bu öğretmenlerin hiçbiri Arapça bilmemektedir. Bazı sınıflar sadece Suriyeli öğrencilerden oluşurken bazı sınıflar hem Türk hem Suriyeli öğrencilerden oluşmaktadır. Ayrıca Suriyeli öğrencilerin sayısı her geçen yıl artış göstermektedir. Böylece bu okullarda karşımıza ilk olarak dil sorunu çıkmakta ve bu sorunla hem öğretmenler hem de öğrenciler mücadele etmektedirler. Okullarda çalışan tercümanlar ise, bu soruna kısmen çözüm getirmektedirler. Bir diğer sorun ise, okullarda birlikte eğitim alan Türk ve Suriyeli öğrencilerin farklı kültürel özelliklere sahip olmalarından kaynaklanan kültürel uyum sorunudur. Bu farklılık zaman zaman öğrenciler arasında anlaşmazlıklara sebep olmakta, bu anlaşmazlıkları giderme görevi de öğretmenlere ve okul yönetimine düşmektedir. Tüm öğrencilerin barış ve huzur içinde eğitim-öğretim görmeleri için öğretmenlerin ve okul yönetimlerinin sürekli olarak bir mücadele içinde oldukları gözlemlenmektedir.

Yukarıda Kilis'te yaşayan Suriyeli çocukların okullarda yaşadıkları birtakım sorunlardan bahsedilmekle birlikte, bu konuda ele alınması gereken bir diğer önemli sorun ise çeşitli sebeplerle okula devam edemeyen okul çağındaki çocuklardır. Özellikle ailesini Suriye'deki savaşta kaybeden ve Kilis'te yakınlarının yanında yaşamını sürdüren çocuklar ile savaşta babasını kaybedip ailesinin geçimini üstlenmek durumunda kalan çocuklar (özellikle de erkek çocuklar) çalışmakta ve bu nedenle 
eğitim hayatından uzak kalmaktadırlar. Eğitim hayatları yarıda kalan ya da başlamadan biten bu çocuklar çalışıp ailelerine ekonomik katkı sağlamak zorunda kalmaktadırlar. Kız çocuklarının okula devam edememelerinin en önemli sebebi ise, çalışma hayatında yer alma zorunluluğundan ziyade çok erken yaşta evlendirilmeleridir. Erken yaşta evlendirilecekleri için okula gitmelerini gerekli görmeyen ailelerin, kız çocuklarını ergenliğe girmeleriyle birlikte evlendirdikleri görülmektedir. Erken yaşta yaptıkları evlilikler ile konuyla bağlantılı olan ve özellikle ülkemizde yaşayan Suriyeli mülteci ailelerin çoğunda görülen çok eşli evliliklerin kurbanı olan kadınlar, araştırma konusunu oluşturmakta ve bu sorunu yaşayan Suriyeli mülteci kadınların hikâyeleri yapılan nitel araştırmayla ortaya çıkarılmaya çalışılmaktadır. Bu bağlamda, bir sonraki başlıkta erken yaşta yapılan evlilik ve çok eşli evlilik konuları detaylı bir biçimde incelendikten sonra araştırma yöntem ve bulgularına odaklanılacaktır.

\section{Erken Yaşta Yapılan Evlilik Ve Çok Eşli Evlilik}

Evlilik, hukuka ve toplum kurallarına uygun olmak koşuluyla, bireylerin özgür iradeleri ile seçtikleri bir yaşam biçimi ve bireysel bir haktır. Evlenmenin geçerli olarak kurulabilmesi için, evlenecek olan kimselerin kanunda belirlenen yaşı tamamlamış olmaları aranmaktadır. Evlenmek için böyle bir yaş sınırının varlı̆̆ı, bir yandan tarafların fiziksel açıdan evlenmenin gerektirdiği koşulları sağlayabilmeleri, diğer yandan da fikri olarak evlenmenin mahiyetini ve beraberinde getireceği birtakım sorumlulukları kavrayabilmek için gerekli olgunluğa sahip olabilmeleri açısından zorunludur. On sekiz yaşın altında olup ruhsal, sosyal ve bedensel gelişimini tamamlamamış, kendi yaşamının kontrolünü henüz sağlayamamış, haklarını bilmeyen (AİLEDER, 2014, s.7) çocukların yaptığı evliliklere, "erken evlilikler" ya da "çocuk evlilikler" adı verilmektedir. Her ne sebeple olursa olsun, çocuk haklarına dair sözleşmeye göre çocuğa yönelik uygulanabilecek aksi kanun olmadığı sürece on sekiz yaş altındaki herkes çocuktur. Ergenlik dönemini kapsayan bu sürecin birey gelişiminde özel bir yeri bulunmaktadır. Özellikle 12-18 yaş arasında ilk olarak fizyolojik gelişme gerçekleşirken, daha sonra psikolojik ve toplumsal gelişme gerçekleşmektedir. Çocuklara fiziksel ya da duygusal anlamda yanlış davranılması, cinsel istismar, ilgisizlik ve ihmalkârlık, 
ayrıca çocukların ticari anlamda ve başka biçimlerde sömürülmesi çocuğa yönelik kötü müdahale olarak değerlendirilmektedir. Çocukluk döneminde yapilan evlilikler de bir istismar olarak kabul edilmektedir. Erken evliliklerin nedenlerine baktığımızda ise, daha çok sosyo-kültürel, ekonomik nedenler ve eğitim yetersizliği kaynaklı gibi görünse de, temelde, geleneksel ve ataerkil toplum yapısından kaynaklı nedenlerle gösterilebilir. Ataerkil birçok toplumda kadının yeri evi olarak algıland1ğı için kadının kaç yaşında evlendiğinden ziyade evinin kadınlığını ve eşlik görevini yerine getirebileceğine yönelik inanışlar daha ağır basmaktadır. Ayrıca, erken evlilikler sonucu birçok fiziksel, ruhsal, sosyal sorunlar ortaya çıkmakta ve özelde kişinin sağlığını, genelde aile ve toplum sağlığını etkilemektedir. Eğitimsizlik, yoksunluk, yoksulluk, şiddet, istismar, erken gebelik ve üreme sağlığı sorunları, anne ve bebek ölüm oranlarında artma ve toplumsal izolasyon gibi sorunların artmasına ve çözüm yollarının azalmasına neden olmaktadır (AİLEDER, 2014, s. 8).

Kadınların maruz kaldıkları önemli bir sorun olan erken evliliğin bağlantılı olduğu ve yine kadınların maruz kaldıkları bir diğer konu ise çok eşli evliliklerdir. Kadınların eşlerinin birden fazla kadınla yaptıkları bir çok eşlilik türü olan "poligini", dünyada özellikle az gelişmiş ya da gelişmekte olan ülkelerde hala rastlanan bir olgu olup özellikle kadınları birçok sorunla baş başa bırakmaktadır.

Çok eşlilik yapısında, ilk ve sonraki evlilikler yapısında ilk ve sonraki eşler aynı evde veya aynı binada başka dairelerde bazen de her eş ve çocuğu farklı binalardaki evlerde yaşayabilmektedir (Slonim-Nevo vd., 2008 akt. Yılmaz vd. 2015). Farklı kültürlere ilk eşin evin içindeki konumu farklı olmaktadır. Birçok toplumda evliliğe ilk katılan kadının kocası üzerinde etkisi güçlü olmakta, ayrıcalıklı ve diğer eşler üzerinde güçlü konumda olmaktadır. Arap toplumlarında ise, ilk eş genellikle daha geri konumda olmaktadır. Aynı evde oturulduğunda yaşanılan kalabalık ortam beraberinde bir takım sorunları da getirmektedir. Tercih temelinde yapılan evlilik ikinci eşe ekonomik kaynakların kullanımı, eşin ilgi ve desteği açısından daha avantajlı bir konum sunmakta bunun sonucu olarak ilk ve sonraki eşler arasında rekabet ve kıskançlık yaşanmaktadır (Al Krenawi vd. 2001'den akt. Yılmaz vd., 2015). Ayrıca ilk eşler için de geçerli olmakla birlikte, özellikle sonraki eşlerin yaşlarının genellikle on 
sekiz yaşın altında olması, hem erken evliliklerle çok eşli evlilik vakalarının bir arada yaşanması da hem de birçok soruna neden olmaktadır.

Ülkemizde 1924 yılında Medeni Kanunla yasaklanan ve sonrasında günümüze kadar konuyla ilgili yapılan pek çok çalışma ile görece azalan çok eşli evliliğin, Suriye' den Türkiye'ye yapılan göçlerle birlikte özellikle ülkemizin Doğu ve Güneydoğu Anadolu Bölgeleri'nde tekrar gündeme geldiğine şahit olunmaktadır. Erkekler için yasal olan çok eşliliğin Suriye toplumunda oldukça yaygın olması, bu ülkeden Türkiye'ye göç eden çok sayıda çok eşli ailenin ülkemize yerleşmesini beraberinde getirmiştir. Suriye'den Türkiye'ye yapılan göçün üzerinden geçen yılların artması ile birlikte, bu aile yapıları giderek ülkemizin özellikle sınır kentlerinin gündem konusu haline gelmiştir. Bu nedenle hâlâ sıcaklığını koruyan bu konu, ülkemizde çok sayıda Suriyeli mülteciye ve doğal olarak çok eşli aileye ev sahipliği yapan sınır kenti Kilis'in de gündemini meşgul etmektedir.

\section{Yöntem}

Araştırma, Suriye'de çıkan savaş sonrası güvenlik endişesiyle ülkelerini terk edip ülkemize sığınan insanların büyük bir kısmının Türkiye'ye ilk adım attıkları şehir olan Kilis'te gerçekleştirilmiştir. Neredeyse her iki kişiden birinin Suriyeli mülteci olduğu bu şehirde çok sayıda Suriyeli kadın mülteci bulunmaktadır. Bu kadınlar içerisinde, eşleri kendilerinden sonra başka bir kadınla ya da kadınlarla evlenmiş, bu nedenle kuması/kumaları bulunan kadınlar da bulunmaktadır. Araştırma kapsamını, Kilis'te yaşayan çok eşli evlilik mağduru olan evli Suriyeli mülteci kadinlar oluşturmaktadır.

Konunun oldukça mahrem, derin ve hassas olması, araştırma kapsamında bulunan kadınların araştırmaya dâhil olmasına önemli engellerden biri olmuştur. Ayrıca araştırmacıların Suriye asıllı olmaması, kadınlar için araştırmacılara olan güven problemini de beraberinde getirmiştir. Bu sıkıntıların yanı sıra, bazı kadınların eşleri, görüşmenin sadece karısı ile yapılacağını ve görüşme sırasında kendilerinin araştırmaya dâhil edilmeyeceklerini öğrenmeleri üzerine araştırmacılara tepki göstermişlerdir. Bu tepki üzerine eşlerinden çekinip araştırmaya dâhil olmak istemediklerini belirten kadınlara da rastlanmıştır. Bahsedilen bu engeller, 
araştırmacıların kurum kimlikleri, çalıştıkları kurumlardan aldıkları izin, araştırmacıların kadınlarla daha sağlıklı bir iletişim gerçekleştirmek amacıyla beraberinde getirdikleri tercümanın kadın olması ve en önemlisi de araştırmacılardan birinin Türk Kızılay'ı personeli olması ile birlikte, Suriyeli mülteci kadınlarla görüşme yapmak mümkün olmuştur.

Araştırmada nitel veri toplama tekniklerinden biri olan derinlemesine görüşme tekniği kullanılmıştır. Mart 2017 tarihinde başlayan görüşmeler, Ağustos 2017 tarihinde tamamlanmıştır. Suriye'de yaşanan savaştan kaçarak ülkemize göç eden, Kilis'te yaşamını sürdüren, kocası kendisinden sonra (Suriye veya Türkiye' de) bir veya birden fazla kadınla evlenmiş toplam 14 kadın ile derinlemesine görüşmeler yapılmıştır.

Suriyeli mülteci kadınların evliliklerine ilişkin hikâyeleri, iki kadın araştırmacı tarafından, kadınlarla aynı zaman ve mekânlarda birlikte yüz yüze görüşülerek toplanmıştır. Görüşmeler, kadınların, kendilerini daha rahat hissetmeleri için, kendi evlerinde ve yanlarında eşleri olmadan gerçekleştirilmiştir. Kadınların evlilikleri ile ilgili bilgilere, katılımc1larla yüz yüze yapılan derinlemesine görüşmelerde onlara yapılandırılmamış ve yarı-yapılandırılmış sorular yöneltilerek ulaşılmıştır. Görüşmelerin tamamı kayıt altına alınmış ve daha sonra transkript edilmiştir.

\section{Bulgular}

Görüşme yapılan Suriyeli mülteci kadınların yaşları 20 ila 58 arasında değişmektedir. Kadınların eşleri tekrar evlenip kendi ifadeleriyle "üstlerine kuma getirdiklerinde" ise, kadınların 20 ila 44 yaş aralığında oldukları tespit edilmiştir. Erkeklerin tekrar evlenmesinde, ilk eşlerinin yaşlarının ilerlemesi ve artık onlara daha fazla çocuk vermeyecek (özellikle de erkek çocuk) olması bir gerekçe olarak gösterilmekle birlikte, görüşmeciler arasında yirmili yaşlarda kadınların bulunması, kadının yaşının kocasının tekrar evlenmesi için bir bahane teşkil etmediğini göstermektedir.

Yedinci görüşmeci, 29 yaşında, okur-yazar değil, ev hanımı, 8 çocuk sahibi. 
"14 yıldır evliyim. 9 yıl önce eşim kuma getirdi. Çok zorda kaldım. Ne yapacağımı bilemedim. Haberim yoktu. Eve gelince gördüm. Kumam oldu."

Kadınların evlilik yaşı, 12 ila 20 arasında değişmektedir. Kadınlardan yalnızca biri lisans mezunu olduğu için 24 yaşında evlenmiştir. Kadınların, ikisi 12 yaşında, ikisi 13 yaşında, ikisi 14 yaşında, ikisi 15 yaşında, biri 16 yaşında, ikisi 17 yaşında, ikisi 20 yaşında ve biri de 24 yaşında evlenmiştir. Suriye toplumunda kız çocuklarını evlendirme kriteri olarak, kız çocuğunun ilk reglini olup ergenliğe girmesi yeterli görülmektedir.

On birinci görüşmeci, 55 yaşında, okur-yazar değil, ev hanımı, çocuk sahibi değil.

"12 yaşındaydım evlendiŭimde. Eşim 24 yaşındaydı. Babam vermişti işte beni. Annelerin de sözü geçmez. 12 yaşında çocuk ne anlar evlilikten. Çocuktum. Bana bilezikler takılmıştı. Onlara seviniyordum. Ilk adetimi evlendikten baya sonra olmuştum. Daha ergenliğe bile girmemiştim."

Evlilik, belirli bir düzeyde fiziksel, duygusal ve psikolojik olgunluk gerektirmekle (Gök, 2016) birlikte, yukarıdaki ifadelerde de gördüğümüz üzere, ergenliğe dahi girmemiş kız çocukları, bilinçli rızaları olmaksızın, babalarının kararları doğrultusunda evlendirilebilmektedirler. Ayrıca kadınların tamamı, evliliklerin gerçekleştirilmesi konusunda annelerinin herhangi bir söz hakkı bulunmadığını belirtmişlerdir.

Geleneksel toplumlarda ataerkil sistem, kadına karşı eşit olmayan muameleyi meşrulaştıran ve sürdürülmesini sağlayan inanç ve normlar ile kız çocuklarının erken evlenmesini desteklemektedir. Ataerkil sistem içinde kadınlara öğretilen toplumsal cinsiyet rolleri erken evliliği işleten mekanizmalardan biridir. Erken evliliğin geçmişten günümüze kadar uzanan ve kadın üzerinden kültürel olarak inşa edilen bir sorun olduğu bildirilmektedir. Erken evlilik birçok toplumda kültürel olarak üretilmekte ve sürdürülmektedir. Toplumsal cinsiyet eşitsizliğinin yaratmış olduğu ayrımcılık sonucunda özellikle kız çocuklarının gözü açılmadan evlendirilmesinin gerektiği düşünülmektedir. Küçük yaşta 
yapılan evlilikle kocaya itaatin ve yeni yuvaya uyumun daha kolay sağlanacağına inanılmaktadır. Erkek aileleri de kendilerine uyumu daha kolay olsun diye mümkün olduğunca küçük yaşta gelin almak istemektedirler. Kız çocuklarının bir an önce bir erkeğin himayesine sokulmasıyla gelebilecek cinsel taciz ve şiddetten korunabileceği sanılmaktadır. Ayrıca bu evliliklerin genç kızların karşı cinsle evlilik dışı ilişkiye girmelerine ve hamile kalmalarına engel olacağı kanaati yaygın bir düşünce olarak görülmektedir (Burcu vd., 2015).

Araştırmaya katılan kadınlar ile eşleri arasındaki yaş farkı incelendiğinde, eşler arasında 2 ila 24 yaş arasında bir fark olduğunu tespit edilmiştir. Kadınlardan sadece ikisinin eşleri, evlendiklerinde 18 yaşın altında olup diğerleri 18 yaşında üstündedir ve kadınlarla aralarında ciddi bir yaş farkı mevcuttur.

Dördüncü görüşmeci, 42 yaşında, ilkokul mezunu, ev hanımı, 6 çocuk sahibi.

“Suriye'de kocanın yaşının büyük olması çok fazla yaygın ve çok normal. Kimse bizim kızımı bekâr, evli, çocuklu adama kız verilmez gibi bir düşünceye sahip değil."

Aileler, kızlarının kendilerinden çok daha büyük yaşta olan erkekle evlenmesini, hayatını kurtarması, namusunu koruması ve ailesini utandırmaması gibi kendilerince önemli olan ancak kız çocuklarının hayatlarını erken yaşta büyük bir baskının altına sokan düşüncelere sahip olmaktadırlar (Çakmak, 2009: 36). Bununla birlikte, çocuk yaştaki evlilik konusunda kadın ile erkek arasındaki yaş farkının daha fazla olduğu evliliklerde genç kız eşinin beklentilerini karşılayamamakta, yaş olarak kendisinden büyük olan erkek de genç bir kızın duygularını ve düşüncelerini anlayamamaktadır. Bu, dünyada değişen nesiller arası iletişim şartları ile birlikte genişleyen nesiller arası uçurumunda bir göstergesidir (Kara, 2015, s.71). Ayrıca, kendilerinden yaşça büyük bir erkekle çocuk yaşta evlendirilen kız çocukları sömürüye, her türlü şiddete ve istismara da açık hale gelmektedir.

Araştırmaya katılan kadınların eğitim düzeyleri incelendiğinde, genel olarak düşük eğitimli oldukları ya da hiç eğitim görmedikleri tespit 
edilmiştir. Kadınların sadece bir tanesi lisans mezunu olup, bir tanesi lise, bir tanesi ortaokul, üç tanesi ilkokul mezunudur. Kalan sekiz kadın ise okuma-yazma bilmemektedir.

Birinci görüşmeci, 30 yaşında, ortaokul mezunu, ev hanımı, 2 çocuk sahibi.

"Abilerim okudu ama bana ortaokuldan sonra izin vermediler. Göğüslerim biraz büyüdü̈̆̈̈ için... Türkiye'de kızlar da okula gidiyor."

Kadınların çalışma hayatına baktığımızda, kadınlar herhangi bir işte çalışmamakta ve kendilerine ait herhangi bir gelirleri bulunmamaktadır. Sadece onuncu görüşmeci, ülkesinde kısa bir süre öğretmenlik yaptığını ancak evlendikten sonra eşinin isteğiyle işini bıraktığını belirtmiştir. Türkiye'de ise, alüminyum doğramacı olan eşinin çalıştığını ve Kızılay Karta sahip olduklarını, bu şekilde evin geçiminin sağladığını belirtmiştir.

Onuncu görüşmeci, 46 yaşında, lisans mezunu, ev hanımı, 4 çocuk sahibi.
"Lisans bitmişti. Matematik öğretmeniydim. Eşim sadece okuma- yazma biliyordu. Herhangi bir mezuniyeti yoktu. Evlenmiştik. Ev- liliğimiz başta güzel gidiyordu. İşi bırakmamı istedi. Bıraktım. Bir daha da çalışmadım."

Kadınların eşlerinin eğitim düzeyleri incelendiğinde, kadınlar gibi onların da genel olarak düşük eğitimli oldukları ya da hiç eğitim görmedikleri bilgisine ulaşılmaktadır. Erkeklerin biri ön lisans, biri ortaokul, dördü ilkokul mezunu olup, sekizi ise okuma-yazma bilmemektedir. Erkekler ülkelerinde yaptıkları işleri, Kilis'e geldiklerinde de devam ettirmektedirler. Erkekler, şoför, inşaat işçisi, fabrika işçisi, kasap, fayansçı, bakır ustası, kunduracı ve alüminyum doğramacı olarak çalışmaktadırlar. Erkeklerin düşük gelirli işlerde çalışmaları, kadınların ise istihdama katılamamaları göz önüne alındığında, ülkemizin Kızılay Kart aracılığıyla sağladığı nakdi yardım ve diğer sosyo-ekonomik yardımların gerekliliği ve önemi ortaya çıkmaktadır. 
Kadınlara çocuk sahibi olup olmadıkları ve çocuk sayıları sorulduğunda, bir kadının çocuk sahibi olmadığı, iki kadının 2, iki kadının 3, iki kadının 4, bir kadının 5, iki kadının 6, bir kadının 7, iki kadının 8, bir kadının ise 11 çocuğa sahip olduğu öğrenilmiştir. Köşeli (2016: 57-148)' nin de aşağıdaki ifadelerinde vurguladığı gibi, geleneksel toplumlarda kadının çocuk sahibi olması, özellikle de erkek çocuk sahibi olması oldukça önemlidir.

"Arap toplumunda sebebi ne olursa olsun çocuk doğuramayan bir kadının ne aile içinde ne de toplum nezdinde hiçbir hükmü yoktur. Doğurgan kadınların önemi ise doğurduğu çocukların erkek olmasıyla doğru orantılıdır. Yani doğurmak ne kadar önemliyse erkek çocuk doğurmak çok daha önemlidir... Oğlu, bir Arap kadınının en büyük güvencesidir. Bu güvenceden mahrum kalmamak için erkek çocuğunu her zaman el üstünde tutar... Kız bebek dünyaya getiren anne ă̆ır hakaretlere ve dayağa maruz kalır bazen de erkek çocuk doğuramadığı için ya boşanır ya da üzerine kuma getirilir."

Kadınların anlatılarında da bu durum açıkça ortaya konmaktadir.

Beşinci görüşmeci, 50 yaşında, ilkokul mezunu, ev hanımı, 8 çocuk sahibi.

"13 yaşında evlendim. 15 yıllık evliydim. 8 çocuğum vardı. Oğlum olmamıştı hiç. Oğlum olsun diye eşim kuma getirdi. Her iki tarafin ailesi de buna razı oldular. Tepki vermediler. İçime oturdu duygularım. Kuma işte gelmişti. Kumamın ilk evliliğiydi. Erkek çocuk da doğurdu. Benden daha kıymetliydi. Her insan gibi eşini kimse paylaşmaz. Kumamla anlaşamazdık. Eş sırası vardı. Haftanın bazı günleri ona giderdi bazı günleri bana gelirdi. 15 yıl kuma ile ayn evi de paylaştım. Çocuklarım için fedakârlık yaptım. Katlandım yaşananlara."

Geleneksel toplumlarda kadının çocuk sahibi olmaması ya da sadece kız çocuğa sahip olması durumunda erkeğin tekrar evlenmesi ve birden 
fazla eşe sahip olmasının sadece erkek tarafından değil, hem kadının hem de erkeğin aileleri tarafından da normal olarak karşılanması oldukça şaşırtıcıdır. Ayrıca erkeğin ikinci eşinin bekâr ve muhtemelen yaşının da küçük olmasına rağmen, evli ve çocuklu (yukarıdaki örnekte sekiz çocuk sahibi) bir erkekle evlenmesinin, yeni eşin ailesi tarafından normal olarak karşılanması ve bu evliliğe onay vermeleri ise daha şaşırtıcı görünmektedir.

Kadınlar, çocuk sebebiyle eşlerinin tekrar evlenmesini büyük bir üzüntüyle karşılamaktadırlar. Ancak görüşme yapılan kadınlarının birinin hikâyesinin oldukça farklı olduğu görülmektedir. İkinci görüşmecimiz, kısır (infertilite) olduğu için eşine çocuk verememenin üzüntüsüyle, eşinin evlenmesini kendisi istemiştir.

İkinci görüşmeci, 41 yaşında, okur-yazar değil, ev hanımı, 6 çocuk sahibi.

"13 yaşında evlendim. Evlendiğimden beri çocuğum olmamıştı. Görmediğim doktor kalmadı. Doktorlar sorunun benden olduğunu söylüyorlardı... Eşim o kadar iyi bir insandı ki. Evlendik yıllar geçtikçe daha çok sevmeye başladık birbirimizi. Eşim kamyon şoförüydü. Ülkeler arası seyahatte ederdi. Kimin çocuğunu görsem ă̆lardım. Benim neden olmuyor diye hep üzülürdüm. Eşime bunu yapmayacağım diye bir söz verdim kendime. Baya zamandır planlıyordum. Kayınvalidemler eşimin evlenmelerinde çok ısrarcı değillerdi ama olsa da fena olmaz tavirları vardl. Allahları var ama hiç biri o kadar yıl yüzüme vurmadılar. Eşim zaten bana üzülüyordu. Hiç dile getirmezdi beni çok severdi. Ama kuma getirdim diye eşimin ailesi memnun oldu. Aslında benim ailem de karşı çıkmadı. Anlamışlardı çok üzülüyordum artık sevdiğim adamdan bir çocuğum olsun ve ben de sevip büyütebileyim.

Çok ağladım kendi ellerimle dü̈̆̈̈̈nlerini yaptım. Eşimin işi gereği bir gün yine Misır'a gitmişti. İşte o geceydi ne zaman döneceğini biliyordum ama dönmesi için plan yapmıştım. Eşime ikinci eşi istedim. Hiç evlenmemiş bir kızd. Bunlar Suriye' de normal, ailesi verdi. Eşimin geleceği gece düğ̈̈n gecesiydi. Ama kendisinin haberi yoktu. Hem mutlu hem üzgündüm. Her şey çeyizler, eşyalar her şey hazırdı. (Düğ̈̈̈n gecesi zılgıt bile çaldım diyerek gözleri dolu dolu anlattı) 
Kumaya düğ̈̈n yaptığım akşam eşim Mısır'dan geldi. Durumu anlattım eşime. Ben çok yıpranıyorum üzülüyorum diye bu evliliği kabul etti. Kısa süre sonra eşimin kumamdan çocuğu oldu... Kumam eve geldikten 4 yıl sonra ben de hamile kaldım. Karnım büyüyordu, regli olamıyordum artık. 17 yıldır evliyim hamile nasıl olunur bilemediğim için kanser olduğumdan korktuk. Doktora gittik. Doktorlar güldü. Müjdeyi verdi. 4 aylık hamileymişim. İnanamadım. Çok ă̆ladım. Mutluluk gözyaşlarıydı. Artık benim de çocuğum olacaktı. Eşim çok fazla mutlu oldu. Eşimin ailesi yaptıklarından bana davranışlarından pişman oldular ama benim onlara davranışım değişmedi. Gün geldi bana da nasip oldu. Kendimi şanslı hissediyorum beklemediğim anda çocuğum oldu. Şimdi altı çocuk annesiyim.

İkinci görüşmeci, araştırmaya katılan kadınlar içinde, eşinin tekrar evleneceğinden haberdar olan tek kadındır. Diğer kadınların durumdan ancak kocalarının ikinci (hatta bazı örneklerde üçüncü) eşi eve getirdikleri zaman haberleri olmuştur.

Dokuzuncu görüşmeci, 42 yaşında, okur-yazar değil, ev hanımı, 8 çocuk sahibi.

"Çocuk yaşta evlendim. 12 yaşındaydım. 22 yıllık evliydim. Başımdan kaynar sular döküldü. Hiçbir sebebi yoktu. Neden yaptı hala bilmiyorum. Eşim araba parçaları satıcısıydı. Bir gün parça almaya Şam' a gideceğim dedi. Meğerse Şam' a gitmemiş. Eşim gidiyorum dedi. 3 gün geçti. Oğlumu sünnet ettirdim bende. Oğlumun tatlısını komşulara dağıtıyorum. Tatlıyı götürdü̈̆̈̈m komşu, kızını kocama vermiş. Haberim yok tabi. Tatlıyı verdim, eve geldim. Eltim evde bana eve gelince söyledi. Onu duyunca merdivenden düşü̈m. İki ayağım birden kırıldı. Oğlum sünnet olmuş benim ayaklarımın ikisi de kırık. Olay oldu üç gün sonra eve kuma ile geldi. Çocuklarım bir ay konuşmadılar babalar ve o kadınla. Nasıl hissedeyim siz düşünün. İki ayă̆ımı birden kırmışım... O zaten bilerek geldi. Hatta ailesi bilerek verdi. Kız 
bekârdı ama komşumken kocama ailecek göz koymuşlar bile bile verdiler kızlarını."

Eşinin tekrar evleneceğinden haberi olmayan dördüncü görüşmeci de yaşadıklarını ağlayarak şu şeklide anlatıyor:

Dördüncü görüşmeci, 42 yaşında, ilkokul mezunu, ev hanımı, 6 çocuk sahibi.

\begin{abstract}
"Ailem yaşamıyor. Eşimin ailesi de yaşamıyordu. Artık biz aile olmuştuk.. 22 yıldır evliyim. İki yıl önce Türkiye' ye geldik. Bir yıl önce bu kadar zor bir durumun ardindan kuma getirdi. Ailemizden hiç kimsenin haberi yoktu. Kuma ile birlikte hiç ayn evde yaşamadık. Sonra onlar Suriye' ye döndüler. Dört yıldır kanser hastasıyım. Hastalı̆̆ına rağmen eşimden çok şiddet gördüm. Hastalı̆̆ının üçüncü yılında da terk etti bizi yeni eşi ile birlikte gitti... Yallarca evliliğimi idare ettim. Ama hep korkmuştum bir gün bana da kuma gelir diye. Sonra yaşlandık. Bu korku aklımdan silinmişti. Ama en silinmemesi gereken yerde silinmiş. Kıskançtı beni seviyor ve kuma getirmez sandım. Ama tam da ona ihtiyacım varken, hastayken beni mahvetti... Kaç yillık eşim bak torunumuz var gelinimiz var. Kaç tane çocuk dünyaya getirdim ben kendisi için. Çok kıskanç bir adamdı. Ama bir gün beni bırakacă̆ı aklıma gelmemişti. Beni kıskanıyordu, şiddet uygulamasına rağmen kıskandığı için beni seviyordu sanıyordum. Aynı yastığa baş koymuştuk yillarca en ihtiyactm olduğu anda beni bıraktı gitti. Hastayım diye mi gitti hala düşünüyorum. Kadının çok genç olduğunu ve ilk evliliği olduğunu öğrendim. Kadını hiç görmedim. Ama görmesem bile hislerim bana yetti. Başka bir kadına tercih edilmek zor, çok zor. Artık yaşamak da istemiyorum.
\end{abstract}

Arap toplumunda hemen her kadın, çocuk sahibi olmak için dilediği sayıda evlilik hakkını erkeğe sunan ataerkil geleneğin aslında erkeğin sadece çocuk için değil, herhangi bir sebepten dolayı, dilediği zaman, dilediği kişiyi eş olarak seçmesi gerçeğiyle karşı karşıya kalmaktadır (Köşeli, 2016: 160). Üstelik bu gerçek, hiç ummadıkları bir anda karşılarına çıkmaktadır. 
On ikinci görüşmeci, 45 yaşında, okur-yazar değil, ev hanımı, 11 çocuk sahibi (çocuklardan beşi işitme engelli)

\begin{abstract}
"Suriye" de bu olaylar yaygin çok fazla. Yilarca tehdit edildim ama sonunda getirdi yine kuma. Beni hiç seomedi. Kumamı şimdi çok seviyor. İkinci eş olmak avantaj katıyor kadınlara. Bu sebeple kızlar da kuma olarak evleniyorlar. Daha kıymetli oluyorlar... Kuma zor iş. Bak 44 yaşındayken kumam geldi ama nasıl zoruma gitti. Evliliğim boyunca zaten tehdit ederdi ama yaptı sonunda. Kızı yaşında birini getirdi. Ona 11 çocuk vermiştim. İstemedim. Karşımda masalarda dans ediyorlar, birlikte duş alıyorlar. Evde genç kızlarım var. Ama babalarının umurunda değil."
\end{abstract}

Eşiyle severek evlenen, üniversite mezunu, hem kız hem erkek çocuk sahibi olan ancak tüm bunlara rağmen kocasının kendisinden sonra iki defa daha evlenmesine bir türlü anlam veremeyen onuncu görüşmecinin son sözleri ise, aslında duruma açıklık getiriyor.

"Ben üniversitedeyken bakışırdık, gizli gizli görüşürdük. Ailemden istedi ailem de verdi beni. Bana da sordular hiç tanışmıyor gibi yaptım olur dedim. Sermek ayıtı, günahtı, bilmiyordu ailem daha önce görüştüğümüzü. Lisans bitmişti. Matematik öğretmeniydim. Eşim sadece okuma-yazma biliyordu. Herhangi bir mezuniyeti yoktu. Evlenmiştik. Evliliğimiz başta güzel gidiyordu. İşi bırakmamı istedi. Bıraktım. Bir daha da çalışmadım.. Sonra on iki yıl geçti bana kuma getirmişti eşim. Nasıl affedebilecektim onu bilemedim. Suriye' de hangi konumda olursanı olun çocuklarınızı ve eşinizi bırakmanız hoş karşılanmaz. Beş yıl kuma ile aynı evde kaldık. Illk kumam geldiğimde eşim 37 yaşındaydı. İkinci kumayı aldığında 48 yaşındaydı. Bu kez Türkiye' ye gelmiştik. Aynı olayları, duyguları yaşamıştım. Ama bu kez farklıydı. Kumam en büyük kızımdan küçüktü. Eşim olacak adam kızı yaşındakine göz koymuştu. Kızım 20 yaşındaydı. İkinci kumam 15 yaşındaydı. Hiçbir kadınlık gururum kalmamıştı... Illk kumam geldiğinde ailem her ne kadar beni geri istemese de doğduğum yerdeydim. Severek de ev- 
lenmiştim konduramamıştım ama olmuştu. İkinci kuma geldiğinde de iyi hissetmemiştim işte... Kız 15 yaşında Suriye'de iken savaştan dolayı annesini kaybediyor. Babası ikinci kez evleniyor. Üvey anneyi sevemiyor. Üvey anne ile sürekli geçimsizlik içindelerken Türkiye' ye kaçmıs. Benim kocam de sinırdan gitmiş arkadaşlarıla kızı almışlar. Eve kuma olarak kızı getirmiş. Karım diye tanıttı."

"Suriye' de bu olaylar yaygın çok fazla. Ama Suriyeli nereye gitse de durum ayni. Bak Türkiye'deyiz ama ikinci kumam Türkiye' deyken geldi. Zihniyet değişmezse mekânlar değişse de olmuyor."

Dinsel ve felsefi inançlar, nüfusu arttırma, çocuk sahibi olma isteği, erkek çocuk istemi, işgücü sağlama, siyasi nedenler, gelenekler, toplumsal örgütlenme, nüfuz ve erk sağlama gibi nedenlere bağlı olarak çok eşli evlilik yapılabilmektedir (Özdemir, 1991). Tüm bu sebeplerin yanı sıra İslam dininin, 'eşler arasında maddi kaynakların eşit dağıtılması ve eşlere adaletli davranmak' şartıyla serbest bırakılmasına (Cin, 1974) dayanarak Suriye Arap Cumhuriyeti' nin erkekler için çok eşli evliliği serbest bırakması, erkeklerin dört kadınla evlenebilmesi için yasal dayanak oluşturmaktadir.

Birinci görüşmeci, 30 yaşında, ortaokul mezunu, ev hanımı, 2 çocuk sahibi.

"Eşim ikinci eşini bana sormadan almıştı. İkinci eş eve geldiğginde benim bir çocuğum vardı. Niçin kuma aldığııı bilmiyorum. Ona çocukta doğurmuştum. Mutluyduk. Anlayamadım kuma getireceğini. Kaynanam da destek olmuş birlikte almışlar. Haber duyduğumda beynimden vurulmuşa döndüm. Çok ă̆ladım. Hiç bu duygulardan kurtulamayacă̆ımı sandım. Kendimi yetersiz ve eksik hissettim. Ne yapacağım bilemedim. Aileme söyleyemedim. Eşimin bir daha benimle olmasin istemedim. Ama ayn zamanda da o kadına bırakamazdım eşimi. Karmaşık duygular yaşadım. Çok yıprandım, yaşlandım. Biraz zaman geçtikten sonra eşime sordum neden böyle bir şey yaptığını, severekte evlenmiştik. Bana bir örnek verdi. Dedi ki; "devlet bana 4 tane hak vermiş, neden haklarımı 
kullanmayayım. Bu duruma alışsan iyi olur. Sana sorsaydım istemeyecektin zaten." Çaresizce evliliğime devam ettim."

"Kuma sistemi maalesef ki Suriye' de çok yaygın. Her durumda erkeğe bir den çok eşlilik hakkı devlet tarafindan verilmiş durumda. Aile cüzdanlarında ve ayn zamanda dinen erkek 4 defa evlilik yapabilir. Bu durum ülkemizde yasaldır. Kadının çocuğu da olsa, eğitim durumu da yüksek olsa fark etmez. Her ne olursa olsun erkek evlenmek isterse devlet destekler. Hatta kadin resmi olarak boşanmak istediğinde birçok sebeple erkek istemiyorsa çok zor boşanır hatta boşanamaz. Erkek istemezse ya da erkek isterse Suriye' de her şeyi yapar.

Suriye Arap Cumhuriyeti vatandaşlarının aile cüzdanları pasaporta benzemekte ve aile cüzdanlarında dört kadının kayıt edilebileceği dört adet bölüm bulunmaktadır. Suriye'de kadınların evlilik yaşı 18 olup daha küçük yaşta yapılan evliliklerde kadınların ailelerinden izin alınıp nikâh kıyılabilmektedir. İlk evlilik belediyelerde yapılan resmi nikâh ile gerçekleşmekte ve aile cüzdanında kadın ve erkeğin bilgileri yer almaktadır. İkinci evliliğini resmi olarak gerçekleştirmek isteyen erkek, ilk eşini hakim huzuruna çıkarmakta ve ilk eşin onayı ve hakimin erkeğin gelir ve sağlık durumunu inceledikten sonra onay vermesi ile resmi olarak ikinci evlilik gerçekleşmektedir. Böylece erkeğin ikinci eşinin bilgileri, aile cüzdanında yer almakta ve kadın erkeğin soyadını resmi olarak almaktadır. Bu süreç üçüncü ve dördüncü resmi nikâhlarda da geçerli olup üçüncü evlilikte ilk iki eşin, dördüncü evlilikte ise ilk üçün resmi makamlarda onayı ve hakimin görüşleri doğrultusunda resmi nikâhlar gerçekleşmekte ve böylece aile cüzdanında bulunan dört bölümde kadınların bilgileriyle doldurulmaktadır. Ancak yukarıda kadınların ifadelerinde de gördüğümüz üzere, genellikle ilk eşlerin, kocalarının başka bir kadınla evlendiğinden ve artık iki karısının olduğundan haberi ancak kocasının yeni eşiyle birlikte eve gelip yeni eşini eski eşine tanıtması ile olmaktadır. Bu durumun sebebi ise, erkekler dini nikâh kıyarak evlenmeleri ve kendisini hemen ikinci (üçüncü, dördüncü) eşine resmi nikâh kıymak zorunda hissetmemesidir. İlk eş ile resmi nikâha sahip olan erkekler, ikinci, üçüncü hatta dördüncü eşleriyle dini nikâh ile evlenmekte 
ve diğer eş/eşleri ile aynı evde veya maddi olanakları yeterli ise başka evlerde yaşayabilmektedir. Erkekler İslam dinini referans alarak bu evlilikleri gerçekleştirmekte fakat İslam dininin birden fazla evlilik için şart koştuğu 'eşler arasında maddi kaynakların eşit dağıtılması ve eşlere adaletli davranmak' hükmünü yerinde getirmedikleri, kadınların yukarıdaki anlatılarından açıkça görülmektedir.

Kadınlar, çocuk yaşta evlilik, aile ve arkadaş ortamından kopma, eğitim hayatlarına devam edememe, çalışma hayatına katılamama, fiziksel ve psiko-sosyal gelişimlerini tamamlayamadan evlenme ve anne olma, ev ve çocuk bakımıyla ilgili tüm sorumlulukları üstlenme, çok sayıda ve özellikle erkek çocuk doğurma stresi, evlilikte duygusal beklentilerinin karşılanamaması, kocalarının kendilerinden habersiz bir veya birden fazla kadınla evlenebilmesi, kocalarının diğer eş/eşleri ile hem kocalarını hem de evlerini paylaşmak zorunda kalmaları, kadınlık gururlarının incinmesi, yoğun stres altında olmaları gibi pek çok sorununun yanı sıra bir de aile içi şiddete maruz kalmaktadırlar.

Altıncı görüşmeci, 29 yaşında, lise mezunu, ev hanımı, 3 çocuk sahibi.

"Her gün döverdi beni. Üç çocuk verdim, yine gözde olmadım. 4 yıl önce kuma getirdi. Çok iyi hatırlıyorum 9 aylık hamileydim. Evde böcek gördüm. Eşim uyuyordu. Korktum uyandırdım. Böceği öldüreceğine beni öldürüyordu döverek. İyi ki savaş çıktı Suriye'de. Türkiye'ye gelmemiz çok iyi oldu. Türkiye'ye geldik beş yıl önce. Geldikten bir yıl sonra da kuma getirdi. Kumamla hiç aynı evi paylaşmadım. Kuma gelince eşimden kurtuldum. Kuma gelince, evden de gitti. Kuma ile yaşıyorlar başka bir evde. Çocuklarıma kıyafet alır arada bu kadar. Başka hiçbir yardımda bulunmaz."

Bir başka görüşmeci ise, eşinden şiddet görmesinin yanı sıra eşi tarafından tecavüze de uğradığını gözleri dolarak dile getiriyor:

Yedinci görüşmeci, 29 yaşında, okur-yazar değil, ev hanımı, 5 çocuk sahibi.

"14 yildır evliyim. Dokuz sene önce eşim kuma getirdi. Kumamla hiç anlaşamadik... Kumam sebebiyle eşim beni çok dövdü. Eşim kumamın lafina giderek 5 aylık hamileyken beni hortum ile dövdü (Görüşme yapıldığında 7 aylık hamileydi. Kendisinin beş çocuğu 
olduğu için ve yaşadığı acılardan dolayı başka çocuğu olmasını istemediğini fakat eşinin onu zorla hamile bıraktığını anlatmıştır)."

Evliliği boyunca eşinden şiddet gören ve bu durumdan ailesinin haberdar olmasına rağmen tüm yaşananlara göz yuman bir diğer görüşmeci ise yaşadıklarını şu şekilde ifade etmektedir:

On dördüncü görüşmeci, 51 yaşında, okur-yazar değil, ev hanımı, 7 çocuk sahibi.

"Şiddet hep vardl. Birçok çocuğum vardı ve üstelik dayak yiyordum. Ama bir de kuma gelmişti. Kuma geldiğinde üstüme 21 yaşındaydım. Evliliğimizin beşinci yılında kuma aldı. Ailemin her şeyden haberi vardı. Ama onlar istemediler ben boşanayım. Onlar evli kalmamı tercih ettiler."

Ailelerinden bekledikleri desteği göremeyen kadınlar, tüm yaşananlara rağmen çaresizce evliliklerine devam etmektedirler.

Sekizinci görüşmeci, 35yaşında, okur-yazar değil, ev hanımı, 3 çocuk sahibi.
“Kumalık Suriye'de yaygındır. Aileler tepki göstermez. Eşim kuma getirdi. Herkes bu duruma hazırdı sanki. Ailelerden kimse de bir şey demedi. Annemlere giderdim çocuklarm var diye beni geri yol- larlardı eşimin yanına. Türkiye'de böyle bir durum yok. Rastlama- dım ben bu duruma hiç Kilis'te."

Sekizinci görüşmecinin yanı sıra kadınların tümü, çok eşli evliliğin Suriye' de yaygın olduğunu ancak Türkiye'de böyle bir duruma rastlamadıklarını, bu nedenle Türkiye'deki kadınların kendilerinden çok daha şanslı olduklarını düşündüklerini ifade etmişlerdir.

Üçüncü görüşmeci, 20 yaşında, okur-yazar değil, ev hanımı, 2 çocuk sahibi. 
"Kuma çok yaygındır Suriye'de. Eşin iyi çıkar da dayak yemezsen şansina. Kadınlar Türkiye'de daha rahat. Eşleri daha modern olduklarn için kadınlar daha özgür."

İkinci görüşmeci, 41 yaşında, okur-yazar değil, ev hanımı, 6 çocuk sahibi.

"Türkiye'de kadınlar daha rahat, daha özgür. Tek eşlilik var. Ama erkek isterse yine yapar da deolet resmi olarak bir eş demiş. Türkiye' deki kadınlar şanslılar."

Çok eşli evliliğin nedenlerini ve sonuçlarını, bu ortak sorunla yüz yüze olan kadınların anlatılarından anlamaya çalıştı̆̆ımız bu araştırmamızda; erkeklerin birden fazla kadınla evlenmelerinin asıl sebeplerinin ne olduğunu, kadınların bu sorunu yaşarken neden yalnız kaldıklarını ve bu durumun kadınlar için sonucunun ne olduğunu, on üçüncü ve on birinci görüşmecilerimiz birkaç cümleyle oldukça çarpıcı bir şekilde gözler önüne sermektedirler.

On birinci görüşmeci, 55 yaşında, okur-yazar değil, ev hanımı, 11 çocuk sahibi.

"Suriye' de bu olaylar yaygın çok fazla. Kuma olmaman için bilinçli bir ailen olması gerekir. $O$ da Suriye' de çok zor. Kumalık için kız doğmuş olman yeterli başka bir şeye gerek yok. Mahkûmsun kuma olmaya bir yerde. Bilinçli çağında olsan da olmasan da.

On üçüncü görüşmeci, 58 yaşında, ilkokul mezunu, ev hanımı, 4 çocuk sahibi.

"Suriye' de bu olaylar yaygin çok fazla. Haberin yokken kuma bulursun kendini. Çok canlar yanıyor çok."

Kadınların tümünün anlatılarından anladığımız üzere, kadınlar evlilik kararı, evlilik töreni, aile yaşamı, çocuk sahibi olma ve çocuk sayısı kararı, evlilik hayatında alınması gereken önemli kararlar, çocukların hayatı ve geleceği için alınan kararlar, boşanma kararı gibi sayabileceği- 
miz pek çok konuda olduğu gibi kocalarının başka kadınlarla evlenmesi kararında da hiçbir söz hakkına sahip olmamakta, ancak bu ve benzeri konuların hepsinde almadıkları kararların sonucuna bizzat kadınlar katlanmaktadırlar. Bu sonuçlar maalesef oldukça zor, acılı ve yıpratıcı olmaktadır. Kadınlar tüm bunlara toplumun yaratmış olduğu toplumsal cinsiyet eşitsizliği nedeniyle yani aslında sadece "kadın" oldukları için çaresizce ve sessizce katlanmaktadırlar.

\section{Sonuç}

Suriye'den Türkiye'ye yapılan zorunlu göçün 2011 yılında başlamasına bugüne kadar geçen sürede canlarını kurtarmak amacıyla ülkemize sığınan milyonlarca insan sadece bir yerden başka bir yere fiziksel olarak yer değiştirmekle kalmamış, aynı zamanda acılarını, yaralarını, umutlarını, daha iyi olacağını düşündükleri yarınları için kurdukları hayalleri ve belirsizlikleri de beraberinde getirmişlerdir. Sığındıkları ülkelerde, yerli halkın bir kısmı tarafından can güvenliği olmayan, mecbur kaldıkları için tüm yaşamlarını arkalarında bırakmak zorunda kalan, yardım edilmesi ve kucak açılması gereken insanlar; diğer kısmı tarafından ise, ülkelerine maddi ve manevi birer yük olarak görülüp bir an evvel savaşın bitmesiyle birlikte, bir şekilde Suriye'ye geri dönmeleri gereken ve bu süre zarfında katlanılması gereken kendilerinden çok farklı bir yaşam tarzına sahip mülteciler olarak değerlendirilmişlerdir. Ancak savaşın uzaması ve Suriyeli mültecilerin göç ettikleri ülkelerde kalma sürelerinin artmasıyla birlikte, sadece can güvenliklerinin ve temel ihtiyaçlarının bir süre karşılanmasının yeterli olmayacağı ve bu insanlara yeni bir hayat ve gelecek de inşa edilmesi gerekliliği ortaya çıkmıştır. Bu doğrultuda hükümetler, yerel yönetimler, sivil toplum kuruluşları ve daha birçok birim kolları sıvamış ve gerekli önlemleri alma yolunda hızla ilerlemiştir. Bu birimler dişında yerel halk da Suriyeli mülteciler de durumun farkına varmış ve onlar da yeni duruma uyum sağlamak zorunda kalmıştır. Hem yerel halk hem de mülteciler, aynı şehri, aynı mahalleri, aynı okulları, aynı hastaneleri, aynı işyerlerini, aynı alışveriş noktalarını kısaca birlikte aynı hayatı paylaşmaya başlamışlardır. Bu yeni paylaşımlar ise zamanla, Suriyeli mültecilerin beraberinde getirdikleri kültürel pratikle- 
rinin, yaşam tarzlarının ve hayata bakış açılarının da fark edilmesine ve bazı unsurların göze çarpmasına zemin hazırlamıştır. Bu unsurların bir tanesi ise, araştırmamızın konusunu oluşturmuştur. Ülkemizde yaşayan Suriyeli mültecilerin kadına, evliliğe ve aile yaşamına bakış açılarının incelendiği bu çalışmada ortaya pek çok gerçek çıkmıştır. Bu gerçeklerden bazıları ise, geleneksel ve ataerkil bir sistemin hâkim olduğu bir toplumdan gelen Suriyeli mülteci kadınların hem çocukluk ve ergenlik dönemlerinde, hem de evlilikleri boyunca kısacası tüm yaşamlarında her zaman erkeklerden geri planda kalmaları ve hayatlarının hiçbir önemli kararında söz sahibi olamamalarıdır. Önce babaları daha sonra da eşleri yani yaşadıkları evlerdeki aile reisleri tarafından onların yerine gerekli kararlar verilmiştir. Bu durum ise kadınları, fiziksel ve psikolojik şiddeti, cinsel istismarı, yoksulluğu, eğitimsizliği, çalışma hayatına adım atamamayı, kendi isteği olmadığı halde çocuk hatta çocuklar doğurmayı, ezilmeyi, hakarete uğramayı, kadınlık onurlarının zedelenmesini ve kendisi gibi aynı kaderi paylaştığı kadınlarla kendi eşini ve bazen de evini paylaşmak zorunda bırakmıştır. Tüm bunlar yaşanırken de ailesi tarafından destek göremediği için, tüm bu yaşadıklarına sessizce katlanmayı öğrenmek zorunda kalmışlardır. Kilis'te yaşayan Suriyeli mülteci kadınların kendi ağılarından dinlediğimiz yaşam hikâyeleri ise, birer masal olmayıp aynı şehirde nefes aldığımız ve birlikte pek çok ortamı (market, pazar, ulaşım araçları, hastane vb.) paylaştığımız bu kadınların yaşadıkları gerçeklerdir. Özellikle çok eşlilik ve kumalık hakkında yaşadıkları ise oldukça hassas, derin, mahrem ve acı dolu olan bu kadınlar için hayatlarında güzel gelişmeler yaşanır mı bilinmez ama bu çalışmanın, ülkemize çok küçük yaşta gelen veya ülkemizde doğan kız çocuklarının kaderinin, annelerinin kaderinden farklı olması için bir nebzede olsa katkısının olması umudunu taşıyoruz. 


\title{
EXTENDED ABSTRACT
}

\section{Second Wife Dram of Syrian Refugee Women: Kilis Sample}

\author{
* \\ İpek Agcadağ Çelik - Feride Vural \\ Kilis 7 Aralık University - Sakarya University
}

After seven years passed over the Humanitarian Crisis in Syria, there has been many changes not only in Syria, but also in many countries of the world, especially in many regions of other countries. Many innocent people have died, and many have been injured in internal conflicts in Syria, and they have lost their relatives, their homes, their financial possibilities and have had to leave their countries. Millions of people who are worried about the safety of both themselves and their families have scattered all over the world leaving their country, particularly countries around the Syrian border facing unprecedented refugees. Due to Syria's proximity with Turkey, the Syrian refugees have fled from Syria to Turkey causing the biggest wave of immigration around the cities of the Syria-Turkish border.

Turkey, with its "open door" policy to all countries as taken in a number of Syrian refuge providing them with citizenship and assistance at hand. In this process, the Turkish government under "temporary protected status" received Syrian refugees, primarily in refugee camps located to the Turkish and Syrian border. However, with the continuation of the conflicts in Syria, the number of Syrian refugees entering the country increased rapidly day by day, causing an inadequate supply with the needs to the Syrian refugees forcing them to move and scatter in many border cities of the country such as Kilis, Gaziantep and Şanlıurfa. Local governments of these cities, which house a large population of Syrian refugees, are dealing with a multi-dimensional problem of economic, social, cultural and psychological issues, including issues such as employment, health, education and security not only local administrations 
but also indigenous people living in border towns and Syrian refugees are trying to adapt with this new issue. With the passage of basic issues such as security, housing, employment, health and education over the past years and with the beginning of adaptation of both the indigenous people and the refugees to this new order, gradually socio-cultural differences have begun to emerge and be recognized. As Castles and Miller (2008) point out, "migrants come from different societies with traditions, religions, habits, different languages and cultural practices are different", show that in their countries they are culturally protecting certain elements of their tongues and cultures for at least a few generation. One of the differences in the country especially in the border cities, that has become more easily due to the refugee density and become one of the agenda issues of the cities is the family structures of the Syrian refugees.

When we look at the degree of women, men and family in the Syrian society shows a traditional and patriarchal structure, the social order and structure are organized against women. This mechanism is most obvious since in issues such as marriage decision, marriage ceremony, family life, child ownership and the decision of the number of children, marriage life, life and future, decision of divorce women have no right to speak or act in these matters. The best example of this situation is undoubtedly the legitimate recognition of the right to marry four spouses by men in the Syrian Arab Republic with a religious reference.

Issues mentioned above in the Syrian society (marriage decision, etc.), with their spouses of getting married to other women, becomes a trouble and suffering of the subject hence upsets us as human being, from Syria with forced migration to Turkey we share the same living spaces with Syrian women.

We see that Syrian refugee women, who have been affected by adverse conditions in their countries, who have lost their relatives, have lost their homes and left their lives behind, and that have taken to a new country and stepped into life, unfortunately polygamy and "second wife" does not make the Syrian women happy.

In their own countries, men are finding solutions to the problems created by the marriage they have made with more than one woman, by providing separate houses or habitats for each of the spouses. However, with the process of asylum, we observe that due to the material and spir- 
itual difficulties they have experienced, most of the men have to live together because there is no opportunity to open a separate house for their spouses in Turkey. This observation has prompted us to learn the stories of these women both in their own country and in our country about marriage and family life. Along with this curiosity, it has become one of the important points of Turkey and the world in terms of migration from Syria, considering the surface area and population, researches were made in the city of Kilis, which has a higher chance of observing, acquiring knowledge and experience with the use of in-depth interviewing, which is a data collection technique of qualitative research method, was preferred because of the very sensitive, intimate and deep structure of polygamy and "second wife".

After this research, the life stories of 14 Syrian refugee women living in Kiliş, their experience of polygamy and their perspectives have been reached. The research, which started on March 2017, was completed on August 2017.

He fled from the war in Syria who emigrated to our country, who lives in Kilis, after her husband (in Syria or in Turkey) was made or in-depth interviews with a total of 14 women who marry more than one woman. The stories of the marriage of the Syrian refugee women were collected by two female researchers, face to face at the same time and place with women. Research was carried out without husbands in their own homes and also women felt more comfortable. Information about marriage of women was reached by in-depth interviews with face-to-face participants and by addressing unstructured and semi-structured questions to them. All of the interviews were recorded and then transcribed. Thus, this study of migration to Turkey from Syria, and the Syrian refugees in Kiliş focused on women's experiences of polygamy.

The findings of our research have enabled us to have a lot of knowledge about women involved in the research. The age of women ranges from 20 to 58, while that getting married ages ranges from 12 to 20. Women stated that the reason for their marriage as a child is that it is enough for girls to enter adolescence as a marriage criterion for girls in Syrian society. 
When the age difference between women and their husbands were examined, it was found that there was a difference between 2 and 24 years of age. When the education levels of women were examined, it was found that they are generally low educated or not educated at all or only one out of the total number of women has a bachelor's degree while their spouses are generally low educated or not at all. It is very important in Syrian society that women have children, especially boys. In addition to this society, if a woman does not have a child or if she only has a daughter, her husband can re-marry and having more than one wife is normally welcomed not only by the man but also by both the woman and the man's family. In the great sadness to the women was if their spouse would be married again, only when their spouses brought the second (or even third in some cases) wife. In Arab society, almost every woman is faced with the fact that the patriarchal tradition presents the right of marriage in which her husband as the right to chose partner he wishes for any reason, not just for the child (Köşeli, 2016: 160). Moreover, this fact comes to fore unexpectedly.

Women, married at childhood, break away from family and friends, unable to continue their educational life, unable to participate in working life, marrying and becoming a mother without completing their physical and psycho-social development, undertaking all responsibilities related to home and child care, women's emotional expectations of marriage not being met, husbands, marriage with one or more women that unaware of their spouse, the sharing of their husbands with another women, the hurting of their pride and the stress as well as domestic violence are exposed. Women who do not see the support they expect from their families continue to marry desperately despite all the living. As we all understand from the facts of the women, women have many issues to consider as marriage decision, marriage ceremony, family life, child ownership and decision of number of children, important decisions to be taken in marriage life, decisions taken for children's life and future, decision of divorce, women do not have any say in the marriage decision, but women themselves endure the decisions that they do not take in all these and similar matters. These results are unfortunately very difficult, painful and worry. Women are helplessly and silently endowed with all these 
because of the gender inequality that society created, that is, they are just "women".

Syrian refugees living in Turkey; Women, marriage, family life and particularly the study of polygamy perspectives and experiences were the first study to be conducted in Turkey. It is not known whether these women, especially those who are very sensitive, deep, intimate and bitter about their experiences of polygamy and second wife, are experiencing beautiful developments in their lives, but this work is a ploy contributing to the fact that the fate of girls born Turkey, very young or from the fate of their mother.

\section{Kaynakça / References}

Aileder (Aile Danışmanları Derneği). (2014). Bilgilen güçlen proje raporu erken evlilik sorunu. http://ailedanismanlari.org/wpcontent/uploads/2014/05/bilgilen-g\%C3\%BC\%C3\%A7lenrapor1.pdf.

Al-Krenawi A, Graham J. ve Izzeldin A. (2001). The psychosocial impact of polygamous marriages on palestinian women. Women Health, 34, 1-16.

Burcu E., Yıldırım F., Sırma Ç. S. ve Sanıyaman S. (2015). Çiçeklerin kaderi: Türkiye'de kadınların erken evliliği üzerine nitel bir araştırma. Bilig/Türk Dünyası Sosyal Bilimler Dergisi, 73, 63-98.

Castles S., Miller J. M. (2008). Göçler Çağı, Modern Dünyada Uluslararası Göç Hareketleri. İstanbul: İstanbul Bilgi Üniversitesi.

Cin H. (1974). İslam ve Osmanlı Hukukunda Evlenme. Ankara: Ankara Üniversitesi Basımevi.

Çakmak, D. (2009). Türkiye'de çocuk gelinler. Birinci hukukun gençleri sempozyumu hukuk devletinde kişisel güvenlik, bildiri tam metinler e-kitabı. Ankara: Ankara Üniversitesi Hukuk Fakültesi, 20-1

Elma F., ve Şahin A. (2015). Suriye'den Türkiye'ye göç ve açığa çıkan temel sorun alanları. https://dokupdf.com/download/suriyeden trkiyeye-g-ve-aa-kan-temel-sorun-alanlar- 5a01f7c3d64ab2b9bd871516 pdf. 
Gök M. (2016). Child marriages in Turkey with Different Aspects. International Journal of Human Sciences,13, 2222-2231.

Güçtürk Y. (2014). Sürgün ile savaş arasinda Suriyeli Mülteciler, http://setav.org/tr/5-soru-surgun-ile-savas-arasinda-suriyelimulteciler/yorum/18059.

Kara B. (2015). Değişen aile dinamikleri açısından erken yaşta evlilikler sorunu ve toplumsal önemi. Süleyman Demirel Üniversitesi İktisadi ve İdari Bilimler Fakültesi Dergisi, 20, 59-78.

Köşeli Y. (2016). Çă̆daş Arap kadin anlatılarında kadının kimlik arayışı. Ankara: Gece Kitaplı̆̆ı.

ORSAM (Ortadoğu Stratejik Araştırmalar Merkezi). (2015). Suriyeli sığınmacıların Türkiye'ye etkileri, Rapor No:195.

Özdemir R. (1991). Tokatta ailelerin sosyo-ekonomik yapısı (1771-1810), aile yazıları I (Temel Kavramlar, Yapı ve Tarihi Süreç), Ankara: T.C. Başbakanlık Aile Araştırma Kurumu Yayınları.

Slonim-Nevo V., Al-Krenawi A. ve Yuval-Shani B. (2008). Polygynous marriage in the Middle East: Stories of success and failures. Ethnology, 47, 195-208.

Türkiye Büyük Millet Meclisi İnsan Haklarını İnceleme Komisyonu. (2014). Ülkemize Sığınan Suriye ve Irak Vatandaşlarının Barındıkları Çadırkentler Hakkında İnceleme Raporu-5, http://docplayer.biz.tr/3250790-Ulkemize-siginan-suriye-ve-irakvatandaslarinin-barindiklari-cadirkentler-hakkinda-incelemeraporu-5.html.

T.C. İçişleri Bakanlığı Göç İdaresi Genel Müdürlüğü. (2018). http://www.goc.gov.tr/icerik6/gecicikoruma 3633784713 icerik.

Üstün N. (2016) Suriyelilerin Türk İşgücü piyasasina enregrasyonu sorunlar-öneriler. http://www.kto.org.tr/d/file/suriyelilerin-turkisgucu-piyasasina-entegrasyonu,-sorunlar-oneriler---nazliustun.pdf.

Yaşar, R. (2014). Kilis'te sığıımacı algısı toplumsal otizm ve ötekileştirme sürecinin ilk görünümleri. Kilis: Kilis 7 Aralık Üniversitesi Matbaası.

Yılmaz E, Tamam L. ve Bal U. (2015). Poligami ve ruh sağlığına etkileri. Psikiyatride Güncel Yaklaşımlar, 7(2), 221-228. 
Kaynakça Bilgisi / Citation Information

Agcadağ-Çelik, İ. Ve Vural, F. (2018). Suriyeli mülteci kadınların kuma dramı: Kilis ili örneği. OPUS - Uluslararası Toplum Araştırmaları Dergisi, 8(14), 341-382. DOI: 10.26466/opus.406308 